\title{
WNK signalling pathways in blood pressure regulation
}

\author{
Meena Murthy ${ }^{1} \cdot$ Thimo Kurz $^{2} \cdot$ Kevin M. O'Shaughnessy ${ }^{1}$
}

Received: 24 August 2016/Revised: 17 October 2016/Accepted: 27 October 2016/Published online: 4 November 2016

(C) The Author(s) 2016. This article is published with open access at Springerlink.com

\begin{abstract}
Hypertension (high blood pressure) is a major public health problem affecting more than a billion people worldwide with complications, including stroke, heart failure and kidney failure. The regulation of blood pressure is multifactorial reflecting genetic susceptibility, in utero environment and external factors such as obesity and salt intake. In keeping with Arthur Guyton's hypothesis, the kidney plays a key role in blood pressure control and data from clinical studies; physiology and genetics have shown that hypertension is driven a failure of the kidney to excrete excess salt at normal levels of blood pressure. There is a number of rare Mendelian blood pressure syndromes, which have shed light on the molecular mechanisms involved in dysregulated ion transport in the distal kidney. One in particular is Familial hyperkalemic hypertension (FHHt), an autosomal dominant monogenic form of hypertension characterised by high blood pressure, hyperkalemia, hyperchloremic metabolic acidosis, and hypercalciuria. The clinical signs of FHHt are treated by low doses of thiazide diuretic, and it mirrors Gitelman syndrome which features the inverse phenotype of hypotension, hypokalemic metabolic alkalosis, and hypocalciuria. Gitelman syndrome is caused by loss of function mutations in the thiazide-sensitive $\mathrm{Na} / \mathrm{Cl}$ cotransporter (NCC); however, FHHt patients do not have
\end{abstract}

Kevin M. O'Shaughnessy

kmo22@medschl.cam.ac.uk

1 Division of Experimental Medicine and Immunotherapeutics, Department of Medicine, University of Cambridge, Cambridge CB2 2QQ, UK

2 Institute of Molecular Cell and Systems Biology, University of Glasgow, Davidson Building, Glasgow G12 8QQ, Scotland, UK mutations in the SCL12A3 locus encoding NCC. Instead, mutations have been identified in genes that have revealed a key signalling pathway that regulates NCC and several other key transporters and ion channels in the kidney that are critical for BP regulation. This is the WNK kinase signalling pathway that is the subject of this review.

Keywords WNK kinases - SPAK/OSR1 phosphorylation · NCC · Ubiquitin-E3 ligase complex · Proteasome . Hyperkalemia · Hypertension

\section{Introduction}

Hypertension (high blood pressure) is a major public health problem affecting more than a billion people worldwide with complications, including stroke, heart failure and kidney failure [1]. The regulation of blood pressure (BP) is multifactorial reflecting genetic susceptibility, in utero environment and external factors such as obesity and salt intake. In keeping with Arthur Guyton's hypothesis, the kidney plays a key role in blood pressure control [2] and data from clinical studies; physiology and genetics have shown that hypertension is driven by a failure of the kidney to excrete excess salt at normal levels of blood pressure. There is a number of rare Mendelian blood pressure syndromes (Fig. 1), which have shed light on the molecular mechanisms involved in dysregulated ion transport in the distal kidney. One in particular is Familial hyperkalemic hypertension (FHHt), a monogenic form of hypertension characterised by high blood pressure, hyperkalemia, hyperchloremic metabolic acidosis, and hypercalciuria [3]. The clinical signs of FHHt are treated by low doses of thiazide diuretics [4], and it mirrors to an extent Gitelman syndrome [5] which features the inverse phenotype of 
Fig. 1 Diagram of the human nephron showing the locations where the main Mendelian syndromes affecting BP operate and the molecular mechanisms involved. The $\mathrm{Na}^{+}, \mathrm{K}^{+}$-ATPase is expressed along the nephron but due to space limitations is only shown in the CD. Abbreviations of nephron segments: $C D$ collecting duct, $D C T$ distal convoluted tubule, $T A L$ thick ascending limb

\section{Mendelian Forms of Blood Pressure Variation}

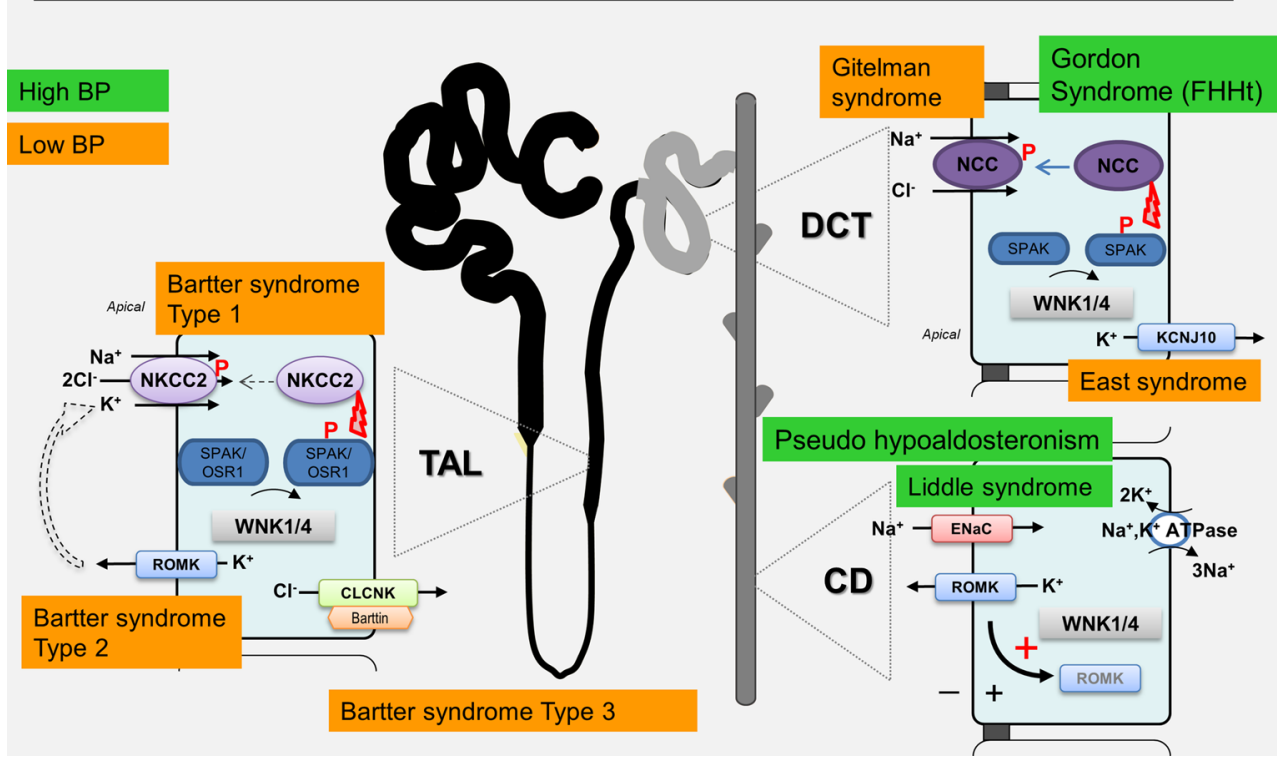

hypotension, hypokalemic metabolic alkalosis, hypomagnesemia, and hypocalciuria. However, it is worth emphasising that FHHt patients are typically normomagnesemic and Gitelman patients are usually normotensive. Gitelman syndrome is caused by loss of function mutations in the thiazide-sensitive $\mathrm{Na} / \mathrm{Cl}$ cotransporter (NCC), but FHHt patients do not have mutations in the SCL12A3 locus encoding NCC. Instead, mutations have been identified in genes that have revealed a key signalling pathway that regulates NCC and several other key transporters and ion channels in the kidney that are critical for BP regulation. This is the WNK kinase signalling pathway that is the subject of this review.

\section{WNK kinases}

The WNK kinases are a family of four evolutionarily conserved serine-threonine kinases (WNK1, WNK2, WNK3 and WNK4) that share $>85 \%$ homology over their kinase domains and form a distinct branch of the phylogenetic tree of the human kinome (Fig. 2) [6]. However, unlike other kinases they use a catalytic Lys residue downstream from the usual site deep in the kinase core (kinase subdomain I). Hence, the term WNK (With No Lys (K)) referring to the absence of the usual N-terminal canonical kinase Lys residue for docking ATP and phosphoryl transfer (e.g. Lys ${ }^{72}$ in Protein Kinase A). This shift to a more superficial and distal glycine-rich loop for their canonical Lys has allowed WNKs to adapt their function and roles by acquiring an important sensitivity to chloride [7] (see "Intracellular $\mathrm{Cl}^{-}$modulates activity of WNK kinases"). Overlap of the 'chloride sensor' in WNKs with the proximal canonical Lys residue explains the use of a distal Lys residue in the WNKs for their kinase activity (e.g. Lys ${ }^{233}$ in WNK1). This unique feature has lead to changes to WNK tertiary structure recently exploited in the development of a highly WNK-selective inhibitor (see "WNK/SPAK/OSR as a druggable signalling pathway").

Another key property of the WNK kinases directly related to their 'chloride sensor' behaviour is inactive and active forms; with phosphorylation stabilising the active state [7]. Chloride anions inhibit this autophosphorylation, which explains how WNK kinase activity can respond to changes in intracellular chloride concentration $\left[\mathrm{Cl}^{-}\right]$and tonicity $[8,9]$. This low $\mathrm{Cl}^{-}$activation occurs rapidly (in $<0.5 \mathrm{~min}$ ) and involves phosphorylation of $\mathrm{Ser}^{382}$ in the T-loop of WNK1, which is conserved across all the WNKs [10]. The discovery of the 'chloride sensor' is recent, but follows long-standing speculation about the existence of a chloride-sensing regulatory kinase to explain the behaviour of $\mathrm{Na}^{+}$and $\mathrm{K}^{+}$cation cotransporters (NKCCs) in determining $\left[\mathrm{Cl}^{-}\right][11]$. The need for this level of control reflects the importance of intracellular chloride in regulating cell volume itself, neuronal function and cell growth [12]. Recent crystallographic data has identified an LGL motif dubbed the 'chloride sensor' in WNK1 that confers chloride sensitivity by blocking the autophosphorylation of the T-loop [7]. This discovery of the chloride-sensing capacity of the WNKs has confirmed them as the 'missing-link' kinase in chloride regulation. It seems likely that WNK1 played a pivotal evolutionary role in controlling cell volume in single cells, although the only unicellular organism with a WNK1 orthologue identified so far is the dimorphic fungus Penicillium marneffei (GenBank: 
Fig. 2 Zoomed section of the human kinome to show the close evolutionary proximity of WNKs and OSR1/SAPK From reference [6] with permission

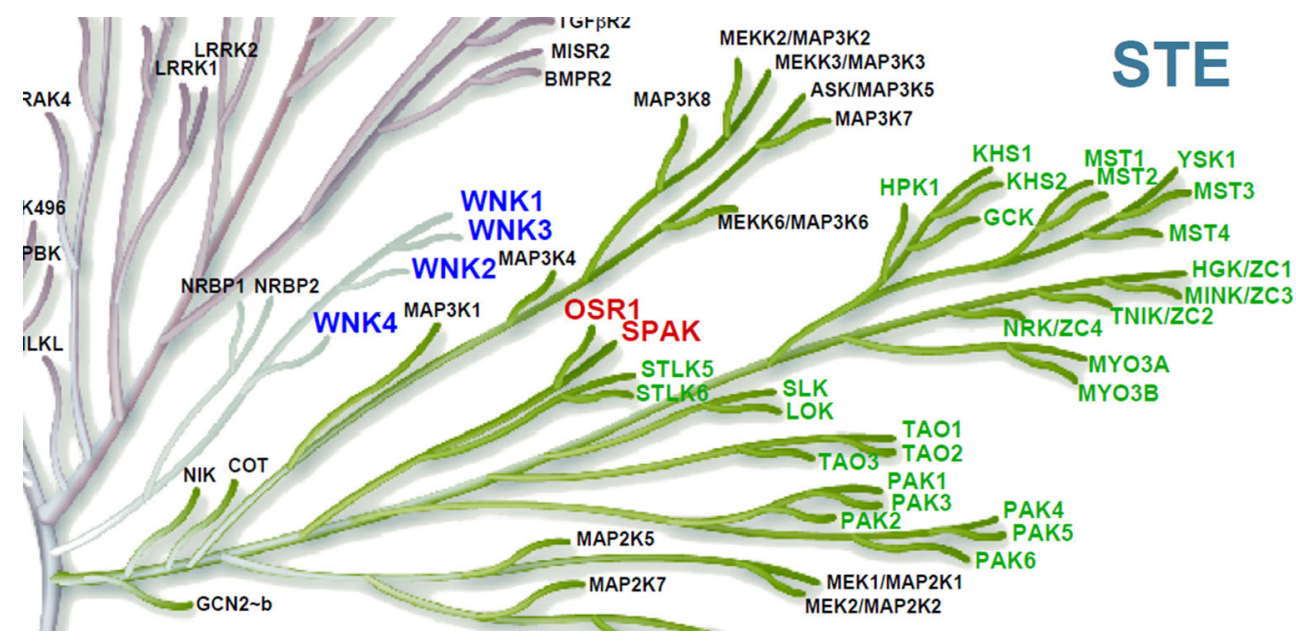

KFX50394.1). The development of closed cardiovascular systems in larger complex metazoan organisms may have necessitated the refinement of its volume regulatory function with gene duplication deriving later WNKs (WNK2-4). What is clear is that the WNKs now have a very diverse biology and a central role in the control of blood pressure.

\section{Inherited hypertension and WNK signalling}

Four different genes have been implicated in FHHt (Table 1; Fig. 1) and two of them encode for WNK kinases: WNK1 and WNK4. The WNK1 sequence was first identified in 2000 from a rat brain cDNA library [13], but its function was unclear until intronic mutations were identified in the WNKl gene in human pedigrees segregating the FHHt phenotype. These mutations were associated with elevated levels of WNK1 messenger RNA in peripheral monocytes from the affected patients and further missense mutations were identified in the orthologous WNK4 gene of other unrelated pedigrees [14]. The other two FHHt genes, CUL3 (Cullin3) and KLHL3 (Kelchlike 3), which were discovered through a whole exome sequencing strategy, regulate WNK kinase levels in the cell. Together Cullin3 and KLHL3 form a Cullin-RING type E3 ubiquitin ligase complex that targets WNK kinases

Table 1 FHHt mutations and their effects on the affected genes

\begin{tabular}{|c|c|c|c|c|}
\hline Gene & Effect & Result & $\begin{array}{l}\text { Effect on the } \\
\text { encoded protein }\end{array}$ & References \\
\hline WNK1 & Deletion of intron I & $\uparrow \mathrm{WNK} 1$ expression & $\begin{array}{l}\uparrow \mathrm{L}-\mathrm{WNK} 1 \\
\text { expression }\end{array}$ & {$[14,25]$} \\
\hline$W N K 4$ & $\begin{array}{l}\text { Missense mutation in the } \\
\text { acidic motif }\end{array}$ & $\begin{array}{l}\uparrow \text { WNK4 expression due to disruption in the KLHL3 } \\
\text { recognition site }\end{array}$ & $\uparrow \mathrm{WNK} 4$ & {$[14,15,17,81]$} \\
\hline WNK4 & $\begin{array}{l}\text { R1185C mutation in the } \\
\text { C-terminal domain }\end{array}$ & $\begin{array}{l}\text { Disrupts a regulatory mechanism involving calmodulin } \\
\text { binding and SGK1 phosphorylation sites }\end{array}$ & Unknown & {$[26,27]$} \\
\hline \multirow[t]{2}{*}{ KLHL3 } & $\begin{array}{l}\text { Missense mutations in the } \\
\text { BTB or BACK domain }\end{array}$ & Disruption of the CUL3-KLHL3 interaction & $\begin{array}{l}\uparrow \mathrm{WNK} 1 \\
\uparrow \mathrm{WNK} 4 \\
\uparrow \mathrm{WNK} 3\end{array}$ & \multirow[t]{2}{*}[15,17,18,81,82]{} \\
\hline & $\begin{array}{l}\text { Missense mutations in the } \\
\text { Kelch propeller blades }\end{array}$ & Disruption of the substrate (WNK) binding & $\begin{array}{l}\uparrow \mathrm{WNK} 1 \\
\uparrow \mathrm{WNK} 4 \\
\uparrow \mathrm{WNK} 3\end{array}$ & \\
\hline \multirow[t]{2}{*}{ CUL3 } & \multirow[t]{2}{*}{ Exon 9 deletion } & Increased KLHL3 ubiquitination and degradation & $\begin{array}{l}\downarrow \text { KLHL3 } \\
\uparrow \mathrm{WNK} 1 \\
\uparrow \mathrm{WNK} 4 \\
\uparrow \mathrm{WNK} 3\end{array}$ & {$[15,17,86]$} \\
\hline & & $\begin{array}{l}\text { Altered CUL3 flexibility leading to CUL3 auto-degradation } \\
\text { and prevention of WNK ubiquitination }\end{array}$ & & [16] \\
\hline
\end{tabular}

$\uparrow$ indicates increase, $\downarrow$ indicates decrease 
for ubiquitination to promote their proteasomal degradation. Cullin3 is a scaffold protein that coordinates the enzymatic and substrate binding activities of the ubiquitin E3 ligase. KLHL3 is the substrate receptor protein that recruits WNKs to the E3 ligase complex to present them for ubiquitination. Once ubiquitinated, WNKs are degraded by the $26 \mathrm{~S}$ proteasome. Mutations in CUL3 cause a dominantly inherited severe form of FHHt $[15,16]$. It has been suggested that these mutations may increase ubiquitination and degradation of KLHL3, preventing WNK recruitment to the ligase complex, and thus indirectly abolishing WNK4 degradation [17, 18]. However, other work has suggested that the mutations affect the molecular flexibility of Cullin3 and lead to its auto-degradation by auto-ubiquitination, without affecting KLHL3 levels [16] ("CUL3KLHL3 as upstream regulators of WNK kinases"). In contrast to CUL3 mutations, mutations in KLHL3 can result in either a dominant or recessive form of FHHt [18]. KLHL3 interacts directly with the CUL3 substrate (WNK in this case) and some recessive KLHL3 mutations directly inhibit this interaction. This prevents WNK ubiquitination and degradation further supporting the notion that elevated WNK levels lead to hypertension [17].

The association of mutations in the WNK kinases with FHHt suggested that an entirely novel pathway existed, connecting WNK kinases with renal electrolyte homeostasis and blood pressure. The last 15 years has been spent unravelling the molecular basis and complexity of this pathway. A crucial feature is the ability of WNK signalling to coordinate two competitive aldosterone-controlled processes: $\mathrm{NaCl}$ reabsorption (from the urine to the blood) and $\mathrm{K}^{+}$secretion (from the blood to the urine) in the distal nephron to regulate blood pressure and maintain electrolyte homeostasis [19]. Work from groups in Yale and Oregon showed that this was achieved by WNKs regulating the phosphorylation and activities of cation-chloride cotransporters (CCCs), including NCC (in the DCT, distal convoluted tubule), KCC4 and NKCC2 (in the TAL, thick ascending limb) [20-22] and the ROMK channel [23], and the epithelial $\mathrm{Na}^{+}$channel $\mathrm{ENaC}$ in the distal tubule and collecting duct [24]. The FHHt mutations reported in WNK1 [14, 25] are large deletions of the first intron that result in an increased expression of WNK1 message, whereas those in WNK4 are missense mutations that are clustered in the highly conserved acidic motif [26]. To date, only one of the WNK4 mutations has been reported outside of the acid motif in the C-terminal domain [27].

Increased expression of WNK proteins alters the quantitative effects that they have on distal ion transport in the kidney, and is the common molecular driver for the $\mathrm{FHHt}$ phenotype. Since the discovery of the WNK kinases, a number of groups have focused on the regulation of NCC and other transporters by WNK proteins including WNK1 and WNK4. Here, we review the current understanding of the molecular signalling pathways used by WNKs, which regulate ion transport in the distal nephron of the kidney.

Renal ion transporters such as NCC and NKCC2 are driven by the favourable $\mathrm{Na}^{+}$gradient established by primary active transport through the $\mathrm{Na}^{+}, \mathrm{K}^{+}$- ATPase $\left(\mathrm{Na}^{+}\right.$and $\mathrm{K}^{+}$-dependent adenosine triphosphatase). NCC, NKCC1 and NKCC2 are the $\mathrm{Na}^{+}$driven $\mathrm{Cl}^{-}$importing transporters that contrast with a more recently discovered family of $\mathrm{K}^{+}$driven $\mathrm{Cl}^{-}$exporting transporters (KCC1-4) [28]. All these transporters are regulated by WNK kinases. In most cell types, the intracellular $\mathrm{Cl}^{-}$concentration $\left(\left[\mathrm{Cl}^{-}\right]_{i}\right)$ is tightly regulated by influx of $\mathrm{Cl}^{-}$through NCCs and an efflux of $\mathrm{Cl}^{-}$via the $\mathrm{KCCs}$. The $\left[\mathrm{Cl}^{-}\right]_{i}$ is crucial for core physiological processes, such as transepithelial solute and water transport, volume regulation and neuronal excitability in neurons [29]. Cell shrinkage or a decrease in intracellular $\left(\left[\mathrm{Cl}^{-}\right]_{i}\right)$, or both, triggers the phosphorylation of NCC, NKCCs and KCCs, which leads to the activation of NCC and NKCCs and inactivation of KCCs, respectively. The converse is true when the $\left[\mathrm{Cl}^{-}\right]_{i}$ is high or when the cell swells, leading to a dephosphorylation of these two sets of transporters and inactivating NCCs, and activating KCCs. Thus, the same signals achieve a tight coordination of $\mathrm{Cl}^{-}$influx and efflux via the inverse regulation of $\mathrm{Na}^{+}$ and $\mathrm{K}^{+}$driven $\mathrm{Cl}^{-}$transport by a common $\mathrm{Cl}^{-}$-sensitive kinase in the form of the WNKs. The fact that this efficient phospho-regulatory mechanism is highly conserved from worms to humans shows how important it is for cell function and survival [30].

\section{Mechanisms of WNK activation, and their downstream targets}

A combination of molecular genetics [14, 31, 32], physiology [19, 20, 33, 34] and biochemistry [35] has shown that the components of the signalling complex downstream of WNK kinases are serine-threonine protein kinases that share high sequence homology. The targets are SPAK (STE20/SPS1-related proline-alanine-rich protein kinase) and OSR1 (or OXSR1, oxidative stress responsive 1) that are closely related members of the STE-20 branch of the kinome (Fig. 2). The kinase domains of SPAK and OSR1 show around $89 \%$ homology, whereas at the whole protein level, the degree of homology is approximately $67 \%$. A major difference between SPAK and OSR1 is the presence of a proline- and alanine-rich region (PAPA box) in the $\mathrm{N}$-terminal domain of SPAK which is upstream of the catalytic domain [36]. There are three different isoforms of SPAK with the full-length isoform (FL-SPAK) being expressed ubiquitously with higher expression in the brain, heart, and testis $[37,38]$. SPAK2, the second isoform, lacks 
the N-terminal PAPA box and a part of the kinase domain, and is also expressed ubiquitously. Kidney-specific SPAK (KS-SPAK) is the third isoform which is expressed mainly in the kidney, as the name suggests. Immunofluorescence studies showed that the FL-SPAK co-localized with NCC at the DCT, whereas SPAK2 and KS-SPAK are more abundant in the TAL, the site of NKCC2 expression [39].

WNKs phosphorylate and activate SPAK and OSR1, which in turn bring about the coordinated phosphorylation of NCC and NKCC2 in the DCT and TAL of the nephron, respectively (Fig. 3). Thus, the SPAK/OSR1 kinases continue the phosphorylation cascade that connects the WNKs and the CCCs. Activation of SPAK and OSR1 takes place in an analogous manner to WNK autophosphorylation with WNKs phosphorylating a conserved Thr residue (SPAK $\mathrm{Thr}^{233}$, OSR1 Thr ${ }^{185}$; Fig. 3) within the SPAK/OSR1 catalytic T-loop motif [19]. The $\mathrm{Ser}^{383}$ is also phosphorylated in SPAK although its functional consequences are unclear [40]. Furthermore, in vitro assays have shown that mouse protein-25 (MO25), which functions as a scaffold, interacts with both SPAK and OSR1, and enhances their catalytic activities [41]. In addition to the catalytic domain, the SPAK/OSR1 have a conserved C-terminal domain (CCT) which is important for docking with the RFXV/I peptide motif in the N-terminus of CCCs such as NCC and NKCCs [9, 42] (Fig. 3). The CCT domain also binds to the RFXV/I peptide motif in WNK kinases bringing them into close proximity with SPAK and OSR1 to activate them. This interaction between the CCT docking domain and WNK kinases plays a major role in blood pressure regulation. OSR1 has been shown to have a highly conserved Leu residue that lies in the base of a deep hydrophobic pocket, and this forms the crucial hydrophobic contacts with the Phe residue of the RFXI motif [43]. Consistent with this in a mouse model carrying a single point mutation (Leu502Ala), the interaction between the docking domain of SPAK and the RFXV motifs on its WNK activators or ion cotransporters is abolished. The mouse also showed reduced phosphorylation and levels of NCC/NKCC2, resulting in a $\sim 20 \mathrm{mmHg}$ reduction in $\mathrm{BP}$ [44].

The realization that both the kinase and the CCT domains are crucial for SPAK/OSR1 function suggested that they could serve as a potential drug targets to screen for novel antihypertensive compounds. The potential for WNK/SPAK/OSR1 to be a druggable signalling pathway is discussed below ("WNK/SPAK/OSR as a druggable signalling pathway").

\section{SPAK kinase is crucial for the phosphorylation and activity of NCC}

The N-terminal tail of NCC has the minimum SPAK binding motif, RFXV/I which has a docking interaction with the C-terminal domains of SPAK/OSR1, which in turn phosphorylates NCC on three highly conserved residues, $\mathrm{Thr}^{46}$, $\mathrm{Thr}^{55}$, and $\mathrm{Thr}^{60}$ (human amino acid numbering; Fig. 3). It has been reported that human NCC can also be
Fig. 3 The domain structure of SPAK and the phosphorylation target sites on NCC, NKCC1 and NKCC2. OSR1 differs from SPAK in lacking the P/A rich (PAPA) domain

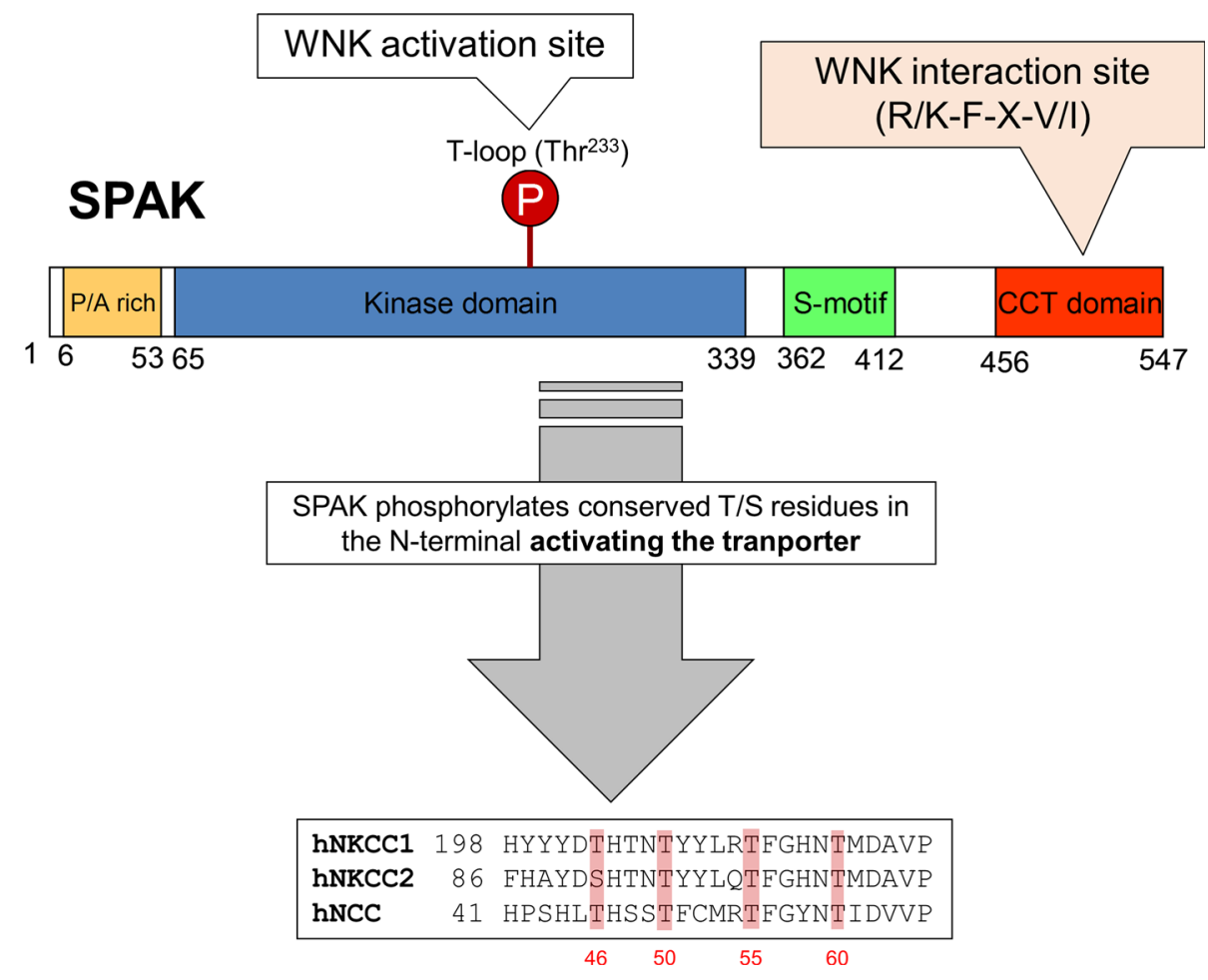


phosphorylated on its $\mathrm{Ser}^{91}$ residue during $\mathrm{Cl}^{-}$depletion by an as yet unidentified kinase [45]. Phosphorylation of $\mathrm{Ser}^{71}$ ( $\mathrm{Ser}^{73}$ in humans) is also altered in SPAK-deficient mice, suggesting that the kinase is essential for the phosphorylation of this site [46]. Although both SPAK/OSR1 kinases are able to phosphorylate NCC in vitro, SPAK is essential for the NCC phosphorylation and activation in vivo.

A number of mouse models have been generated (Table 2) to characterize the SPAK kinase function: (1) a global knockout which inactivates the full-length and truncated forms of SPAK [39, 44, 46]; (2) a kinase ablating knock-in mutant (SPAK $\mathrm{T}^{243 \mathrm{~A} / 243 \mathrm{~A}}$ ) where a missense mutation in the T-loop of SPAK prevents its activation by WNKs, and (3) a knock-in mutant ( $\mathrm{SPAK}^{\mathrm{L} 502 \mathrm{~A} / \mathrm{L} 502 \mathrm{~A}}$ ) which is SPAK CCT domain defective and leading to markedly reduced SPAK activity and phosphorylation of CCCs such as NCC and NKCC2 [44]. In all the models, NCC phosphorylation is markedly reduced, and both the SPAK $^{\mathrm{T} 243 \mathrm{~A} / \mathrm{T} 243 \mathrm{~A}}$ and SPAK ${ }^{\mathrm{L} 502 \mathrm{~A} / \mathrm{L} 502 \mathrm{~A}}$ knock-in mutants display features of Gitelman syndrome.

Genetic inactivation of OSR1 causes embryonic lethality due to defective angiogenesis and cardiovascular development [47, 48] (Table 2). The targeted inactivation of OSR1 in the distal nephron results in hypokalemia and a mild volume depletion due to the reduced expression, phosphorylation and activity of NKCC2, clinical symptoms similar to Bartter syndrome [47]. These mice show an increased NCC and phosphoNCC expression which probably compensates for the decreased NKCC2 activity. The expression and phosphorylation of $\mathrm{NKCC} 2$ was reduced in both SPAK $^{\mathrm{T} 243 \mathrm{~A} / \mathrm{T} 243 \mathrm{~A}}$ and $\mathrm{SPAK}^{\mathrm{L} 502 \mathrm{~A} / \mathrm{L} 502 \mathrm{~A}}$ knock-in mutants, but there was an increase in the SPAK knockout mice. This difference might be due to the inhibitory effect of shorter SPAK isoforms on NKCC2, which are present in the knock-in models but not in the knockout mice. These results show that SPAK activates NCC, and that OSR1 cannot fully compensate for its absence. A recent double knockout mouse (lacking both SPAK and OSR1 activity) supports this, but also showed that there was substantial phoshoNKCC2 still present in the medulla suggesting another unrecognised kinase is important for NKCC2 phosphorylation [49].

\section{SPAK as a blood pressure risk allele for essential hypertension}

Essential hypertension (EH) unlike the rare single gene Mendelian forms such as FHHt is caused by the effects of tens of genes whose impact is modified by gene-gene interactions and epigenesis [50, 51]. In fact, the genes coding for proteins in the WNK signalling cascade do not feature in the genetic architecture of $\mathrm{EH}$. The gene encoding SPAK, STK39, is a singular exception. It covers $300 \mathrm{~kb}$ of chromosome 2 and was first identified as a hypertension susceptibility locus in a Genome-Wide

Table 2 Mouse models in which SPAK-OSR1 have been genetically modified

\begin{tabular}{|c|c|c|c|c|c|}
\hline Gene & Genetic modification & $\begin{array}{l}\text { Effect on blood } \\
\text { pressure }\end{array}$ & $\begin{array}{l}\text { Expression and } \\
\text { activity of NCC }\end{array}$ & Phenotype & References \\
\hline \multirow[t]{7}{*}{$S P A K$} & $S P A K^{-/-}$ & $\begin{array}{l}\downarrow \text { with a } \mathrm{Na}^{+} \\
\text {depleted diet }\end{array}$ & $\downarrow \downarrow$ & Hypokalemia with $\mathrm{K}^{+}$depleted diet & [39] \\
\hline & $S P A K^{-1-}$ & ND & $\downarrow \downarrow$ & $\begin{array}{l}\text { Vasopressin induced NCC phosphorylation } \\
\text { No NKCC2 phosphorylation }\end{array}$ & [125] \\
\hline & $S P A K^{-1-}$ & ND & ND & Decreased $\mathrm{NKCC} 2$ mediated $\mathrm{Na}^{+}$reabsorption & [126] \\
\hline & $S P A K^{-1-}$ & $\downarrow$ & $\downarrow \downarrow$ & Gitelman syndrome & [46] \\
\hline & $S P A K^{-1-}$ & ND & ND & $\begin{array}{l}\text { Na absorption in the TAL blunted, vasopressin } \\
\text { stimulation of NKCC } 2 \text { intact }\end{array}$ & [127] \\
\hline & $S P A K^{T 243 A / T 243 A}$ & $\downarrow$ & $\downarrow \downarrow$ & Gitelman syndrome & [38] \\
\hline & SPAK $^{\mathrm{L} 502 \mathrm{~A} / \mathrm{L} 502 \mathrm{~A}}$ & $\downarrow$ & $\downarrow \downarrow$ & Gitelman syndrome & [44] \\
\hline \multirow[t]{3}{*}{ OSR1 } & $O S R 1^{-1-}$ & NA & NA & Embryonically lethal & [48] \\
\hline & $\begin{array}{l}\text { Kidney-specific inactivation ( } K S P- \\
\left.\quad O S R 1^{-/-}\right)\end{array}$ & Normal & $\uparrow \uparrow$ & Bartter syndrome & [47] \\
\hline & $O S R 1^{+/-}$ & $\downarrow$ & $\uparrow \uparrow$ & Bartter syndrome & [47] \\
\hline $\begin{array}{l}\text { SPAK/ } \\
\quad \text { OSR } 1\end{array}$ & $\begin{array}{l}S P A K^{-l-} / O S R I^{\text {flox/flox }} / \mathrm{Pax} 8-\mathrm{rtTA}^{+} / \mathrm{Cre}^{+} \\
\text {double knockout }(\mathrm{DKO})\end{array}$ & $\downarrow$ & $\downarrow \downarrow$ & $\begin{array}{l}\text { pNKCC } 2 \text { levels still high } \\
\text { Compensatory changes in NKCC2 and NCC }\end{array}$ & [49] \\
\hline
\end{tabular}

$\uparrow$ indicates increase, $\downarrow$ indicates decrease and number of up or down arrows the size of the effect

$N A$ not applicable, $N D$ not determined 
association study of the Pennsylvania Amish [52]. It was replicated in several other Amish and non-Amish Caucasian cohorts. The blood pressure effect size of the strongest STK39 alleles was up to $3 \mathrm{mmHg}$ in the Amish, but smaller and less consistent across the other groups. Some of the alleles were also relatively frequent in these populations at $>9 \%$. However, the association has not been replicated in other studies notably those using a black American cohort [53] and in the Chinese Han. Although one study in Han Chinese found association in obese not in non-obese children [54], suggesting the allele is actually an obesity risk factor. A more recent meta-analysis of almost 22,000 hypertensives has confirmed the association in Europeans and East Asians but not Black American hypertensives [55]. So, it remains unclear whether the association of BP with STK39 alleles is a false positive one or is population specific. The latter is suggested by a study in Northeastern Chinese Han people indicating that the association in the Han is regionally distinct and involve the interplay of several STK39 alleles (rs6749447, rs35929607 and rs3754777) [56].

While the influence of STK39 genetic variation on blood pressure is not clear, genetic variation in its phosphorylation target, NCC, is important. Over 100 mutations in the SCL21A3 gene, which encodes for NCC, have been documented in patients with Gitelman syndrome. Amongst the missense mutations within the coding region one is highly relevant to WNK signalling: T60M (homologous to mouse $\mathrm{T}^{58}$ ). It inactivates one of the key Thr residues for NCC activation and is a frequent mutation in South Asia [57] (Fig. 3). Mice homozygous for this mutation recapitulate the Gitelman phenotype very closely [58].

\section{WNKs as upstream regulators of SPAK in NCC activation}

WNK1, WNK3 and WNK4 are expressed in the kidney, and the $W N K 1$ gene produces two isoforms, a long isoform called the L-WNK1 and a shorter, kidney-specific WNK1 (KS-WNK1). The L-WNK1 contains the entire kinase domain and is expressed ubiquitously, whereas the KSWNK1 is devoid of the kinase activity, and is expressed only in the distal nephron. Initial studies on the effect of L-WNK1 on NCC in in vitro systems such as cell lines or Xenopus oocytes showed that this form of WNK1 had no effect on NCC expression or activity, but it abolished the inhibitory effect of WNK4 on NCC [59, 60]. However, L-WNK1 activated SPAK by phosphorylation, which indicated that it could activate NCC in a SPAK-dependent manner [45, 61]. The relevance of these pathways in vivo could not be tested because the L-WNK1 knockout models were embryonically lethal with developmental defects in the cardiovascular system, similar to those observed in OSR1-deficient embryos (Table 2) [48, 62, 63]. However, a mouse model with human WNK1 mutations (large deletions of the first intron of the WNK1 gene) fully recapitulated the FHHt phenotype showing an increase in L-WNK1 specifically in the DCT and CNT, with no changes in KS-WNK1 expression. Increased NCC expression and phosphorylation was also noted, and these WNK1 $1^{+/ F H H t}$ mice displayed an increased level of SPAK phosphorylation in the DCT, and more abundant SPAK levels at the apical membrane of the DCT when compared with wild-type mice. The FHHt phenotype was maintained in these mice even in the absence of WNK4. Thus, this study indicated a L-WNK1/SPAK pathway for NCC activation $[24,25]$.

WNK3 also activates NCC by a kinase- and SPAKdependent mechanism, similar to L-WNK1 [64, 65]. WNK3 does not activate NCC in the absence of its kinase activity, and interestingly, the kinase dead WNK3 mutant is a potent inhibitor of the cotransporter. This shows that in the absence of activation, WNKs can have an opposite effect (or dominant-negative effect) on their target protein [65, 66]. WNK3 knockout mice have a very mild phenotype, and show a slight decrease in blood pressure during salt depletion. Their kidneys have an increased expression of L-WNK1, where it probably compensates for the absence of WNK3, and thus maintains NCC phosphorylation [67].

The effect of WNK4 on NCC is paradoxical, with both in vitro and in vivo studies showing that WNK4 can behave as an inhibitor as well as an activator of NCC [68]. Although these discrepancies in the literature now have to be viewed in the knowledge that $\left[\mathrm{Cl}^{-}\right]$was a potential unrecognised confounder in these reports (see "Intracellular $\mathrm{Cl}^{-}$modulates activity of WNK kinases"). Most in vitro studies have shown that WNK4 inhibits NCC activity by abolishing the effect of WNK1 or WNK3 on NCC [69]. In vitro studies involving Xenopus oocytes showed that angiotensin II (AngII) signalling increased NCC activity by abolishing the inhibition by WNK4 of the cotransporter, and this effect required AngII, its receptor AT1R, and WNK4, and was prevented by the AT1R antagonist losartan. The effect of AngII on NCC was dependent on SPAK kinase because a dominant-negative SPAK or the removal of the SPAK binding motif in NCC prevented activation of NCC by AngII signalling, and this was also reported in the mpkDCT cell expression system [70]. In vivo studies in mice have shown that WNK4 is essential for basal phosphorylation and activation of NCC through its interaction with SPAK. WNK4 inactivation resulted in a significant reduction in NCC expression and activity, and this is associated with hypokalemia and metabolic alkalosis. The absence of WNK4 also abolished 
the stimulatory effect of AngII on phosphorylation of SPAK and NCC [71]. The converse of this, overexpression of WNK4 in a transgenic mouse model, was consistent in producing a Gitelman-like phenotype [71].

\section{Intracellular $\mathrm{Cl}^{-}$modulates activity of WNK kinases}

As discussed in "WNK kinases" in this review, crystallographic studies of WNK1 in its inactive state, and in the presence of $\mathrm{Cl}^{-}$revealed that the anion binds directly to the catalytic domain, which could be the basis for the unique positioning of the catalytic lysine residue. This work by Piala et al. [7] showed that WNK1 fragments have a putative chloride-binding pocket formed by $\mathrm{Leu}^{369}$ and Leu $^{371}$ in the DLG motif (Fig. 4), and the binding of $\mathrm{Cl}^{-}$ prevents WNK1 autophosphorylation. Therefore, the higher the intracellular $\left[\mathrm{Cl}^{-}\right]$, the lower the level of autophosphorylation and hence reciprocal activation of WNK1. The effect of WNK4 on NCC within whole cells is also modulated by intracellular $\left[\mathrm{Cl}^{-}\right]$. A recent study in Xenopus oocytes has shown that WNK4 has an inhibitory effect on NCC in normal solutions, whereas when exposed to low $\left[\mathrm{Cl}^{-}\right] /$hypotonic conditions, it activates the NCC and thus promotes $\mathrm{Cl}^{-}$efflux and a decrease in intracellular $\left[\mathrm{Cl}^{-}\right.$] [68]. Mutating Leu ${ }^{322}\left(\mathrm{Leu}^{369}\right.$ in L-WNK1) resulted in the constitutive phosphorylation and activation of WNK4, and thus stimulation of NCC by WNK4 in control conditions. Thus, intracellular $\left[\mathrm{Cl}^{-}\right]$modulates the inhibitory versus activating effect of WNKs on NCC [68] and the discrepancies previously reported in vitro (see "WNKs as upstream regulators of SPAK in NCC activation") probably reflect unrecognised differences in intracellular $\left[\mathrm{Cl}^{-}\right]$. Work by Terker et al. [72] has further shown that although the $\mathrm{Cl}^{-}$binding pocket is conserved by all the WNK kinases, it is WNK4 that has the highest sensitivity to $\left[\mathrm{Cl}^{-}\right]_{i}$. This is especially striking over the physiological range thought to exist within a DCT cell $(10-60 \mathrm{mM})$ (Fig. 4) [73].

\section{Extracellular $\mathrm{K}^{+}$as the ultimate regulator of WNK/SPAK/NCC pathway}

Recent work from the Ellison group has provided compelling evidence that the activity of the WNK/SPAK signalling pathway in the DCT is regulated by the plasma $\mathrm{K}^{+}$or more precisely the concentration of $\mathrm{K}^{+}$in the peritubular fluid [72]. It does this through its effects on the membrane potential of DCT cells (Fig. 5). Using HEK cells expressing NCC as a model for the DCT cell, they showed that levels of phosphoNCC and phosphoSPAK were directly affected by the extracellular $\mathrm{K}^{+}$with a low $\mathrm{K}^{+}$increasing the levels of both proteins. This effect of $\mathrm{K}^{+}$ was inhibited by both $\mathrm{Rb}^{+}$and $\mathrm{Ba}^{2+}$ (to block $\mathrm{K}$ channels). Since Kir 4.1(KCNJ10; Fig. 5) is the predominant K channel in the DCT, they further showed that if mutants of this channel (which cause a Gitelman-like syndrome in humans) were expressed in the HEK cells it both depolarized them and reduced phosphoNCC levels.

A previous model for the DCT that incorporates a basolateral $\mathrm{KCl}$ cotransporter and a CIC channel predicted that depolarization would reduce intracellular $\left[\mathrm{Cl}^{-}\right][74]$, and they were able to demonstrate this in their HEK model using a chloride-sensitive fluorescent dye. Discovery of a chloride sensor in WNKs (see "WNK kinases" and "Intracellular $\mathrm{Cl}^{-}$modulates activity of WNK kinases") provides an elegant explanation for coupling of extracellular $\left[\mathrm{K}^{+}\right]$to $\mathrm{NCC}$ function through alteration in
Fig. 4 Shows the relation between the phosphorylation state of SPAK in vitro and the concentration of $\mathrm{Cl}^{-},\left[\mathrm{Cl}^{-}\right]$. The latter is sensed through the chloride sensor motif on the WNKs that directly inhibits WNK kinase activity. Over the physiological range (highlighted in pink) WNK4 shows the greatest sensitivity to $\left[\mathrm{Cl}^{-}\right]$. KD here means kinase domain From reference [66] with permission
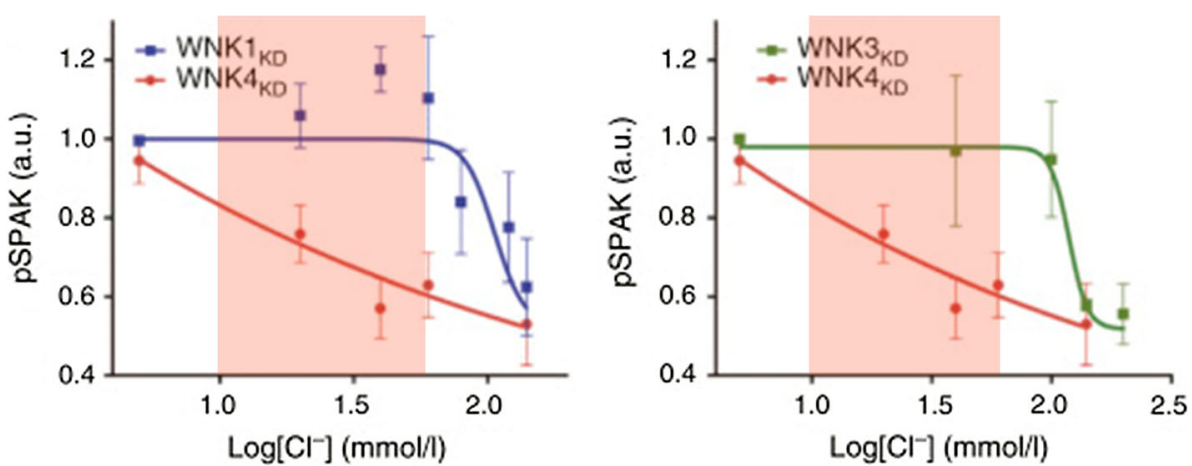

CHLORIDE SENSOR

WNK1 VKIGDLGLATLKRASF 379

WNK2 VKIGDLGLATLKRASE 353

WNK3 VKIGDLGLATLMRTSF 305

WNK4 VKIGDLGLATLKRASF 332 
Fig. 5 Diagram showing the hypothetical model for regulation of NCC

phosphorylation in the DCT cell, and hence the level of transcellular $\mathrm{NaCl}$ flux. Activity in the WNK/SPAK/NCC pathway is directly regulated through the extracellular $\left[\mathrm{K}^{+}\right]$, causing parallel changes to intracellular $\left[\mathrm{Cl}^{-}\right]$and WNK4 kinase activity
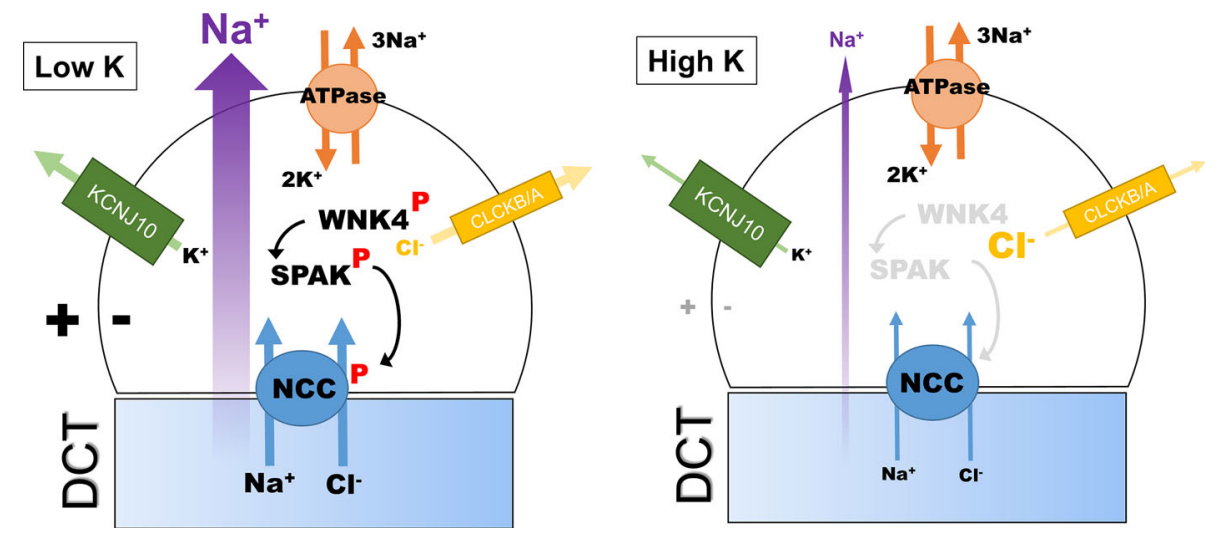

intracellular $\left[\mathrm{Cl}^{-}\right]$. The Ellison group tested this directly by expressing WNKs with mutated chloride sensor motifs to render them insensitive to intracellular $\left[\mathrm{Cl}^{-}\right]$[72]. The HEK cells no longer responded to changes in extracellular $\left[\mathrm{K}^{+}\right]$and showed increased levels of phosphoWNK consistent with unrestricted WNK autophosphorylation. They also showed that this derepressive effect of chloride sensor mutation was much larger for WNK4 than other WNKs [72]. This is in keeping with the in vitro sensitivity of the WNK4 to $\left[\mathrm{Cl}^{-}\right]$(Fig. 4) and probably explains why WNK4 has become the most important WNK for DCT function.

The model proposed by Ellison has been partly verified using a more physiological approach using perfused mouse kidney and ex vivo slices [73]. Once again low extracellular $\left[\mathrm{K}^{+}\right]$causes rapid phosphorylation of NCC through WNK/SPAK/OSR1 pathway activation. Using microperfused DCT tubules, the authors were also able to show that membrane potential changes at the luminal surface were most important. However, in contrast to Ellison they found that the dephosphorylation that occurs with high extracellular $\left[\mathrm{K}^{+}\right]$was not dependent on $\mathrm{Cl}^{-}$. This suggests that the dephosphorylation is regulated by so far undisclosed signalling molecules that are not part of WNK/SPAK signalling.

\section{CUL3-KLHL3 as upstream regulators of WNK kinases}

While mutations in $W N K 1$ and $W N K 4$ are known to cause FHHt, only about $13 \%$ of the affected pedigrees show mutations in these two genes [75]. As discussed in the introduction, recent studies have reported that mutations in CUL3 and KLHL3 also cause FHHt [15, 18]. CUL3 belongs to a protein family that consists of seven Cullins (Cul1, -2, -3, -4a, -4b, 5, and -7), which are all involved in the degradation of intracellular proteins by forming ubiquitin E3 ligases [76, 77]. These so-called Cullin-RING ligases share a common architecture, in which the Cullins act as the scaffold for nucleation of other E3 ligase subunits (Fig. 6). Ubiquitin E3 ligases are the final enzymes in an enzymatic cascade that leads to the ubiquitination of target proteins. Prior to ligation by E3s, ubiquitin is activated by an E1 activating enzyme and transferred to E2 conjugating enzymes [78]. The E3s are the most critical step, as they provide substrate specificity and are also often subject to regulation. The Cullins themselves are $80-100 \mathrm{kDa}$ in size and structurally consist of an elongated $\mathrm{N}$-terminal domain and a globular C-terminal domain. The very $\mathrm{N}$-terminus of the Cullin binds to substrate adaptor and receptor proteins to recruit the substrate for ubiquitination. The E3 ligase activity resides in the C-terminus and is mediated by a small RING finger protein, either Rbx1 or Rbx2, which stably interacts with the Cullin C-terminus and recruits ubiquitin-charged E2 enzymes to transfer ubiquitin onto the substrate protein [79] (Fig. 6). Because of their modular setup, the CullinRING E3s are the largest class of ubiquitin E3 ligases in mammals.

Most of the seven Cullin proteins interact with their own unique set of substrate adaptor and receptor subunits. In the case of Cullin3, these are the so-called broad complex/tramtrack/bric-a-brac (BTB) proteins [76], which are characterised by BTB domains that mediate the interaction with CUL3. One subclass of BTB proteins are the Kelchlike (KLHL) proteins, a family of more than 40 Cullin3 substrate adaptors/receptors, which includes KLHL3. Kelch proteins connect the substrates to the Cullin3-RING ubiquitin ligase through their Kelch domains (Fig. 6) [80]. Kelch domains form beta propellers and X-ray crystal structures of the KLHL3 Kelch domains bound to WNK peptide revealed multiple sites of interaction, which involve residues that are mutated in FHHt patients in either WNK4 or KLHL3 [16, 17]. Indeed, mutant WNK4 proteins carrying mutations within the so-called acidic motif cannot be immunoprecipitated with KLHL3 in vitro (Ref. [17]).

Mutations in both CUL3 and KLHL3 are predicted to impair the degradation of WNK kinases. The majority of 
Fig. 6 Cartoon to show the effect of different mutations in WNKs, KLHL3 or CUL3 on the docking of WNKs with the Kelch-like-3/Cullin-3-RING type E3 ubiquitin ligase complex. The situation for the wild-type is shown at top right. All the mutations ultimately block WNK ubiquitination, and hence its degradation by the proteasome

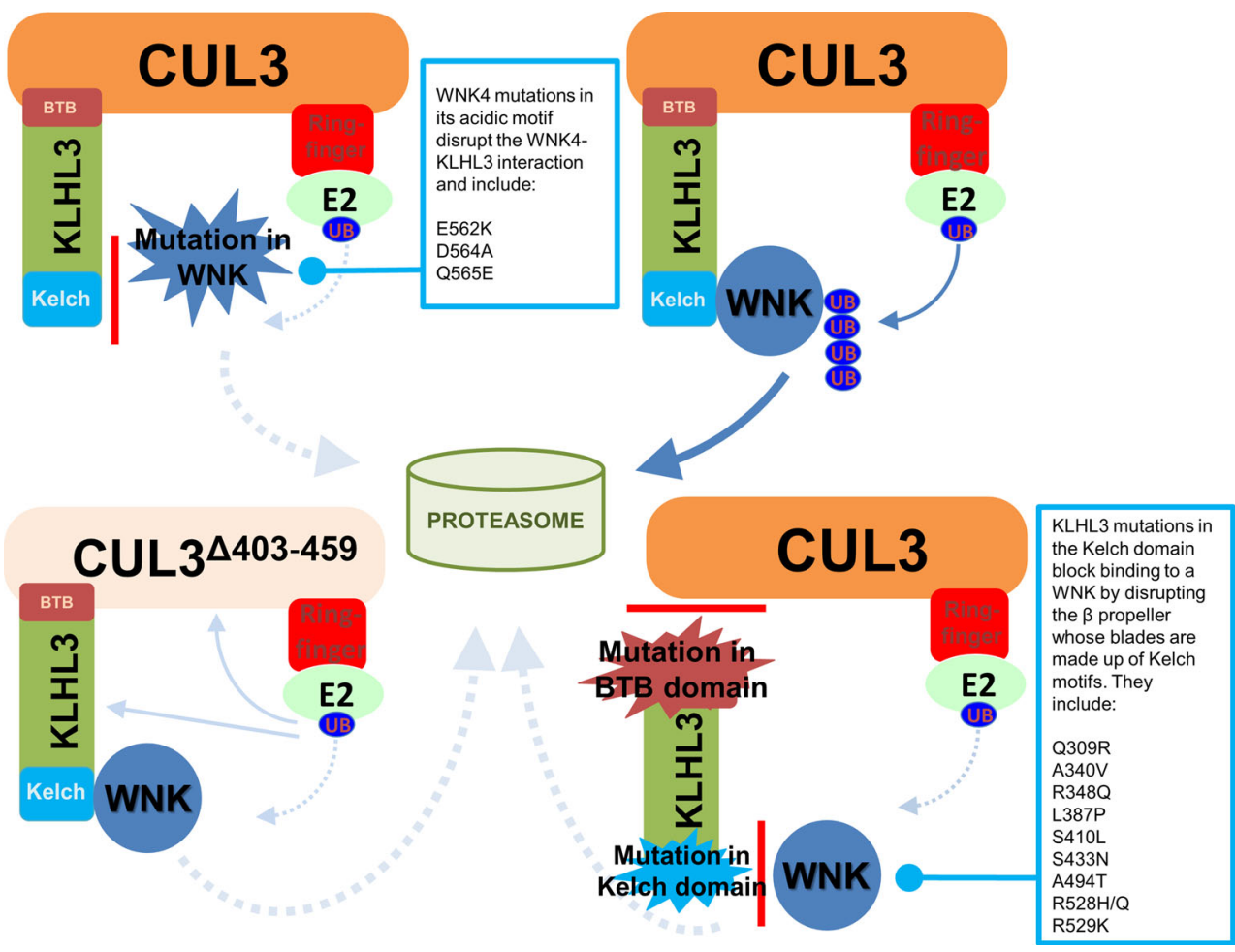

FHHt-linked KLHL3 mutations either disrupt binding to CUL3 or WNKs (see Fig. 6) to prevent the formation of an active E3 ligase. FHHt-causing mutations in KLHL3 directly block their interaction with WNK4, which reduces its ubiquitination and levels in both mammalian cells lines and kidney lysates from a mouse model expressing a typical acid motif FHHt mutation (WNK4 ${ }^{\text {D561A }}$ [81]). This provides an elegant molecular explanation for how these mutations stabilise WNKs by preventing their degradation by ubiquitination and removal by the proteasome [17]. The findings that these mutations also cause FHHt strongly support the idea that both WNK1 and WNK4 activate NCC $[15,18,82]$. Further, knock-in mice with FHHt-like mutations in KLHL3 [R528H] have been reported to have an increased abundance of WNK1 and WNK4 proteins and increased NCC activity. In this model, Arg528 that makes critical interactions with the WNK4 degron motif is mutated, and the mice displayed a marked increase in blood pressure [83]. This presumably caused activation of the WNK/SPAK/OSR1 kinase cascade and hypertension through excess activity of the WNK/SPAK/NCC pathway.

Mutations in both CUL3 and KLHL3 are predicted to impair the degradation of WNK kinases. In fact, most FHHt-linked KLHL3 mutations either disrupt binding to CUL3, which stops assembly of the E3 complex, or to WNKs, which prevents WNK recruitment to the E3 (Fig. 6). Both mechanisms ultimately result in a loss of WNK ubiquitylation and degradation [17]. The findings that these mutations also cause FHHt strongly support the idea that both WNK1 and WNK4 activate NCC [15, 19, 73]. Further, knock-in mice with FHHt-like mutations in KLHL3 [R528H] have been reported to have an increased abundance of WNK4 proteins and increased NCC activity. In this model, Arg528 that makes critical interactions with the WNK4 degron motif is mutated, and the mice displayed a marked increase in blood pressure and increased abundance of WNK1 and WNK4 isoforms [74]. Similarly, transgenic heterozygous mice expressing a version of WNK4 that carried a familial FHHt mutation in the KLHL3 binding site (D561A/+) displayed increased WNK4 levels and overexpression of WNK4 in transgenic mice leads to FHHt-like phenotypes [81]. This stabilization of WNKs presumably caused activation of the WNK/ SPAK/OSR1 kinase cascade and hypertension through excess activity of the WNK/SPAK/NCC pathway. Furthermore, it is unlikely that NCC and SPAK are directly regulated by CUL3/KLHL3, as neither protein interacts with KLHL3 [17]. This strongly suggests that the FHHt phenotype is mediated by a loss of WNK ubiquitylation and degradation, which can be caused by mutations in either the ubiquitin E3 or its WNK substrates.

Interestingly, although FHHt patients with mutations in CUL3, KLHL3 or WNK present the same clinical symptoms, those with mutations in CUL3 have a more severe phenotype, evident in terms of both an earlier age-of-onset and the degree of hypertension and electrolyte disturbance reported [15, 84, 85]. So far, all the reported FHHt CUL3 mutations show the deletion of exon 9 in the CUL3 mRNA 
which results in the loss of amino acid residues 403-459 in the protein. These mutations are heterozygous and autosomal dominant [15, 84, 85]. Two different mouse models of CUL3 have been reported, to date. The first is a nephronspecific deletion of CUL3 that showed the expected increase in WNK kinase levels as well the phosphorylated form of NCC [86]. However, the absence of CUL3 lead to an extended phenotype that is not typical of an FHHt phenotype. Specifically, the mice showed renal dysfunction with hypochloremic alkalosis, diabetes insipidus, and saltsensitive hypotension. Levels of NKCC2 and AQP2 were depleted, and the loss of CUL3 leads to a widespread tubulointerstitial inflammation and fibrosis within the kidney. The second model is a knock-in mouse model for the exon 9 deletion of CUL3 which exhibited a typical FHHt phenotype, and the absence of homozygous knock-in mice for the exon 9 deletion suggested that this mutation is lethal in utero as a homozygote [16]. The heterozygous animals, CUL3 ${ }^{\text {WT/ }} 403-459$ exhibited significantly higher blood pressure, and an up-regulated WNK kinase pathway similar to the WNK4 mouse models for FHHt (WNK4 D568E [87, 88] and KLHL3 R528H [89]). They showed elevated levels of urine electrolytes with hyperkalemia, hyperchloremia and a compensated metabolic acidosis. These mice had higher aldosterone levels which are more likely driven by the hyperkalemia. Interestingly, in addition to the increased absorption of salt through NCC in the DCT, the CUL3 ${ }^{\text {WT/ }} 403-459$ mice displayed a thickened aortic wall, altered aortic pulse pressure waveform and in vivo responses to pressor agents that together suggested these mice have an increased contractile state in their vasculature, Thus, the novel vascular phenotype in the CUL3 ${ }^{\mathrm{WT}}$ / $\Delta 403-459$ mice, in addition to the hypertension due to salt retention could possibly explain why FHHt due to CUL3 mutations result in a more severe form of the disease in comparison to FHHt due to mutations in WNK1, WNK4, KLHL3.

The vascular phenotype of the CUL3 ${ }^{\mathrm{WT} / \Delta 403-459}$ mice may have been anticipated from work done on families with mutations in the nuclear hormone receptor peroxisome proliferator-activated receptor gamma gene (PPAR $\gamma)$. These patients have an intriguing phenotype that includes lipodystrophy, metabolic syndrome and severe insulin resistance, but they also have early onset and severe hypertension [90]. The molecular basis for the hypertension was studied in a transgenic mouse model [91], which showed increased RhoA and Rho-kinase (ROCK) activity in its aorta and an increased contractile state to its of vascular ex vivo. RhoA protein (the ROCK GTPase regulator) is ubiquitinated and degraded in an analogous manner to WNKs except that the adaptor/substrate protein is not KLHL3 but the related adaptor protein RhoBTB1. This suggested that contraction reflected activation of the phosphorylation cascade through ROCK that controls myosin light chain activation in vascular smooth muscle. Hence, the deletion mutation in Cullin 3 would be predicted to alter the contractile state of blood vessels by reducing Cullin3-RING ligase activity causing secondary accumulation of RhoA (cf WNKs). This scenario would also suggest that the abnormal vascular phenotype in FHHt is restricted to pedigrees with CUL3 but not KLHL3 mutations.

The molecular consequences of the exon 9 deleted form of mutant Cullin3 have been explored by several groups. Araki et al. [92] attempted to produce knock-in mouse models expressing the exon 9 deleted protein by knocking in two CUL3 human mutations that affect splicing: $\mathrm{G}(-1) \mathrm{A} /+$ and $3 \mathrm{~T}(-6) \mathrm{G} / \mathrm{T}(-6) \mathrm{G}$ [92]. Neither of the models produced the expected CUL3 ${ }^{\Delta 403-459}$ protein, presumably because of species differences in CUL3 splicing. Instead, the mutations appeared to behave as null alleles with the total CUL3WT protein being suppressed by 50 and $25 \%$, respectively. Importantly, neither mouse showed an FHHt phenotype. The authors reported that no truncated forms of CUL3 were detected in their mice, although close inspection of the published western blots (Fig. 4A; Ref [92]) suggests there were faint bands from a lower MW form. Of note, the low abundance of the truncated CUL3 ${ }^{\Delta 403-459}$ protein was similarly difficult to demonstrate in the mouse reported by Schumacher et al. [16]. Hence, it is possible that splice processing in the models produced by Araki et al. generated minor truncated forms of CUL3 that did not mimic either the Schumacher mouse or the human processing defect.

The exon 9 deleted mutant Cullin3 protein has also been overexpressed in HEK cells to study its effects. This appeared to show that it produced reduced RhoA ubiquitination and degradation suggesting a dominant-negative effect against wild-type Cullin3 protein in vivo [93]. However, the dominant-negative effect observed in HEK cells may be secondary to marked substrate adaptor protein depletion. It is also likely that in FHHt patients with CUL3 ${ }^{\Delta 403-459}$ there are very low tissue levels of the exon 9 deleted Cullin3 [16]. Structural modelling combined with biochemical verifications has also shown that the CUL3 ${ }^{\Delta 403-459}$ mutation provides the Cullin3 protein with greater flexibility, which probably arises from the exon deletion splicing together two unstructured regions by removing three alpha helices. The greater flexibility impedes its scaffolding function, and prevents the CUL3 $^{\Delta 403-459}$-RING ubiquitin ligase complex from directing ubiquitin towards the bound substrates, and instead leads to increased ubiquitination of itself and Kelch3. In fact, in vivo studies indicate that the CUL3 ${ }^{\Delta 403-459}$ auto-ubiquitinates itself first, as only relatively low amounts of CUL3 $3^{\Delta 403-459}$ are detectable in 
tissue from the mouse model, while the levels of KLHL3 are unaffected. This auto-degradation of CUL3 ${ }^{\Delta 403-459}$ could be a major cause for the associated phenotype in patients.

Data from in vitro studies [16] show detectable CUL3 ${ }^{\Delta 403-459}$ in cells, but this protein is unable to ubiquitinate WNK kinases, suggesting that the exon 9 deletion in CUL3 is a loss of function mutation with respect to substrate ubiquitination. Yet the mutant CUL3 $^{\Delta 403-459}$ protein also failed to inhibit CUL3 ${ }^{\text {WT }}$, so it may not exert a dominant-negative effect in vitro. So how is the CUL3 ${ }^{\triangle 403-459}$ mutation able to produce its effect in vivo? FHHt patients with the CUL3 ${ }^{\Delta 403-459}$ mutation are heterozygotes, and therefore retain a functional copy of the gene. This means the CUL3 ${ }^{\Delta 403-459}$ mutation either behaves as a dominant-negative to inhibit CUL3 ${ }^{\text {WT }}$ or it is haplo-insufficient with respect to blood pressure regulation, with a single copy of CUL3 being unable to fulfil its physiological functions including WNK degradation. Nevertheless, the work published to date does not resolve which of these scenarios is correct and more work is needed.

Blood pressure is maintained by tightly regulated ion transporters in the epithelia of the distal nephron, which balance the influx and efflux of salt, and the activities of these transporters depend on their phosphorylation by WNK kinases, as discussed in this review. The phosphorylation of NCC/NKCC 2 by WNK kinases is controlled by two complementary mechanisms: the regulation of total WNK protein levels by CUL3-KLHL3, and the level of WNK activation by phosphorylation. To date, the mechanisms that sense either the need for the phosphorylation of WNK kinases or their degradation by CUL3-KLHL3 is not known, or this would be an area for future research.

The discovery of a vascular phenotype in the CUL3 ${ }^{\text {WT/ }}$ 4403-459 mice takes the role of WNK kinases in blood pressure regulation outside of the kidney. What needs confirmation is whether this vascular phenotype is a primary phenomenon or secondary to hypertension driven by $\mathrm{NaCl}$ retention from NCC activation. The CUL3 ${ }^{\text {WT/ }}$ $\triangle 403-459$ mice have an altered aortic pulse waveform and slowed diastolic relaxation that is consistent with stiffening of their arterial tree. An increase in the contractile state of the vasculature due to wall thickening possibly contributes to the hypertension in addition to increased salt reabsorption at the distal nephron in these mice [16]. The WNK1/ WNK3/SPAK/OSR1 pathway is thought to be important for regulating vascular tone by controlling the phosphorylation state of the NKCC1 cotransporter, and hence the membrane potential of vascular smooth muscle (VSM) cells $[46,94,95]$. The role of WNK/SPAK kinases in smooth muscle contraction, and angiogenesis is discussed in detail in "WNK/SPAK signalling and vascular smooth muscle contraction" and "WNK signalling and angiogenesis" of this review.

\section{Non-kinase dependent effects of WNKs}

The WNKs regulate expression of several channels and transporters that may directly or indirectly impact on the regulation of blood pressure, e.g. the Cystic Fibrosis Conductance Regulator (CFTR), renal outer medullary K channel (ROMK) and the epithelial $\mathrm{Na}^{+}$channel (ENaC). These effects are generally kinase-independent and cause altered expression of the target proteins at the cell surface. They may also operate in tandem with kinase-dependent effects through WNK/SPAK/OSR1 signalling, although they have distinct time domains. Hence, in the case of NCC, altered expression at the cell surface occurs within $15 \mathrm{~min}$ of exposure to ATII [96], requires WNK4 and represents altered trafficking. In contrast, the activation of NCC by phosphorylation in the same system is only apparent after $60 \mathrm{~min}$ of ATII stimulation and requires SPAK reflecting WNK/SPAK signalling activation.

In terms of molecular mechanisms, WNK4 reduces NCC expression at the cell surface by diverting the forward trafficking of NCC from the trans-golgi network to lysosomes. It does this by increasing complex formation with the adaptor protein AP-3 that is part of a cargo delivery system moving proteins to the lysosome compartment [97]. This makes use of $\mathrm{YXX} \varphi$ recognition motifs present in the $\mathrm{N}$ and C-terminal sequence of NCC. It is unclear to what extent this mechanism is generalizable to the trafficking of other WNK targets whose cell surface expression is affected. Certainly, the interaction of WNKs with CFTR, $\mathrm{ENaC}$ and ROMK channels do not follow this model.

Expression of the CFTR in Xenopus oocytes is reduced by WNKs with WNK4 reducing channel expression at the cell surface through a kinase-independent mechanism [98]. However, the effect of WNKs on CFTR expression is dependent on context as more recent work has highlighted a kinase called spleen tyrosine kinase (SYK) as having an important negative regulatory role in modulating CFTR channel expression [99, 100]. It does this through phosphorylation of a single tyrosine residue $\left(\mathrm{Y}^{512}\right)$ close to the common mutation site in CFTR $\left(\mathrm{F}^{508}\right)$. There is cross-talk between SYK and WNKs with WNK4 sequestering SYK and preventing $\mathrm{Y}^{512}$ phosphorylation of the CFTR channel [99]. The alteration of CFTR expression can impact BP and both cystic fibrosis patients and mice with reduced CFTR expression have lower BP [101]. It has been speculated that the prevalence of $\mathrm{CF}$ mutations in the population reflects their protective effect against the development of hypertension. Nevertheless, the exact mechanism for the hypotensive effect of reduced CFTR expression is not clear 
as the CFTR is widely expressed in transporting epithelia in the gut, sweat glands, kidney and lung. Recent work in mice even suggests this may be due to reduced aortic contractility by affecting calcium mobilization [102].

The ENaC channel is expressed in the distal nephron where it regulates $\mathrm{Na}^{+}$reabsorption giving the channel a pivotal role in salt homeostasis and the long-term control of BP. Expression and activity of $\mathrm{ENaC}$ is regulated by the hormones vasopressin (ADH) and aldosterone. Vasopressin recycles channels to the cell surface from a recycling pool [103] while aldosterone drives the synthesis of new ENaC channels and a kinase, serum-glucocorticoid regulated kinase 1 (SGK1), that stabilises expression of $\mathrm{ENaC}$ at the cell surface [104-106]. The ENaC channels are normally cycled from the cell surface after ubiquitination by the ubiquitin E3 ligase Nedd4-2 and phosphorylation of Nedd4-2 by SGK1 reduces its interaction with ENaC [105]. The WNKs interact at several points in this process. First, WNK1 can bind and activate SGK1, although this is not a catalytic effect [107] and seems to be common property of the N-terminal of all four WNKs [108]. WNK4 also reduces $\mathrm{ENaC}$ expression at the cell surface. This effect is independent of Nedd4-2 so that it is able to reduce surface expression of ENaC subunits that lack the YY motifs necessary for interaction with Nedd4-2 [109]. Finally, WNK4 is itself a substrate for SGK1, although its phosphorylation at Ser1169 confers the unusual property of reversing its action against $\mathrm{ENaC}$ [110].

The ROMK channel is expressed only in the kidney. In the distal nephron, ROMK functions as an important secretory channel for $\mathrm{K}^{+}$. Since serum $\mathrm{K}$ tightly regulates the synthesis and release of aldosterone ROMK expression can also modulate BP. It also directly impacts $\mathrm{Na}^{+}$ homeostasis as $\mathrm{Na}^{+}$reabsorption in the thick ascending limb of the loop of Henle is limited by local $\mathrm{K}^{+}$recycling through ROMK. The surface expression of ROMK is again suppressed by WNKs, but the molecular details are distinct from their effects on ENaC trafficking. Specifically, ROMK is not internalised by WNKs (WNK1 and WNK4) through an ubiquitination pathway. Instead, accelerated internalisation of ROMK is dynamin-dependent and involves clathrin-coated pits $[111,112]$.

\section{WNK/SPAK signalling and vascular smooth muscle contraction}

The role of the NKCC1 cotransporter in chloride-transporting epithelia and in the control of cell volume [113] is well established. Less well appreciated is its role in the vasculature in controlling blood vessel tone. Although, $\mathrm{Cl}^{-}$ entry into smooth muscle cells generally depolarises the membrane potential and contracts them [114]. NKCC1 is the only SLC12A3 sodium-chloride cotransporter expressed in the aorta, and its key role in $\mathrm{Cl}^{-}$entry into vascular smooth muscle was confirmed by deletion of the transporter in the mouse. The blood pressure in $\mathrm{NKCCl}^{-1-}$ mice was substantially lower than wild-type controls [115]. Electrolyte and aldosterone levels were unaffected in this model implying that salt and water homeostasis was intact. However, venous smooth muscle ex vivo showed less tone and a reduced vasorelaxation to bumetanide. A subsequent study has shown an effect of NKCC1 inhibition on the resistance vessels as well [116]. The components of the WNK/SPAK/OSR1 pathway are present in aortic vascular smooth muscle and NKCC1 is regulated by phosphorylation of N-terminal Ser/Thr residues homologous to those present in the N-terminus of NCC and NKCC2. Confirmation of the pathway was provided by a SPAK knockout mouse that had low blood pressure, reduced aortic phosphoNKCC1, and reduced aortic responses to phenylephrine and bumetanide. The level of phosphoNKCC1 in the aorta responds directly to dietary levels of salt in the mouse with a low-salt diet increasing phosphoNKCC1 [95]. This effect of dietary salt is mimicked by AngII and blocked by the ATIR receptor antagonist valsartan. Hence the WNK/ SPAK/NKCC1 cascade in vascular smooth muscle appears to be regulated physiologically by the renin-angiotensin system.

There is some uncertainty over which various WNK isoforms is most important in the vessel wall. WNK1 deletion $\left(W N K 1^{-l-}\right)$ is lethal in utero, but mice with haploinsufficiency for WNKl $\left(W N K 1^{+/-}\right)$have reduced pressor responses to phenylephrine and reduced contraction in vitro to $\alpha$-adrenergic contraction. Isolated vessels also showed reduced myogenic responses to load [94]. In contrast, the WNK/SPAK/NKCC1 cascade was not activated by ATII or dietary salt restriction in a WNK3 knockout mouse. This mouse also showed reduced pressor responses to infused ATII [95]. This suggests that both WNK isoforms have a role in the vessel wall with WNK1 perhaps being more important for catecholaminergic tone and WNK3 for regulation by the renin-angiotensin system.

\section{WNK signalling and angiogenesis}

Mice with homozygous deletion of the WNK1 gene $\left(W N K 1^{-l-}\right)$ die in utero before embryonic day 13 [63]. The development of the heart is abnormal and both sprouting and remodelling angiogenesis is impaired in WNK1 null embryos. By crossing Tie2-Cre with floxed WNK1 mice, it has been shown that it is the endothelial-specific loss of WNK1 that causes the angiogenesis defects [62]. The resulting mice are striking for showing ectopic expression of venous markers in arteries and arterial markers in veins. 
This suggests that WNK1 is acting beyond the differentiation switch that determines whether a nascent vessel follows an arterial or venous fate. The arterial differentiation switch is dependent on the activation of VEGF/Notch signalling and the existence of cross-talk between VEGF and WNK signalling has been suggested by recent work in Zebrafish [117]. In this model vertebrate species WNK signalling is again important for the formation of the vessels of the head and trunk. Of note, knock-down of WNK1 with morpholino antisense oligos produced similar defects in Zebrafish angiogenesis to knock-down of the VEGF2 receptor itself. The VEGFR2 is the major receptor mediating VEGF effects in the vasculature and its Tyrosine Kinase (TK) function activates downstream kinases including phosphoinositide-dependent protein kinase (PI3 kinase). PI3 kinase in turn activates another kinase, Akt/ $\mathrm{PKB}$, which is an important kinase in mediating the metabolic and mitogenic effects of insulin. There is a clear biochemical opportunity for cross-talk between VEGF and WNK1 signalling, since the N-terminal of WNK1 has a phosphorylation consensus sequence for Akt/PKB1, and IGF-1 stimulates phosphorylation of the conserved $\mathrm{Thr}^{60}$ residue in this sequence in HEK cells [118]. This event seems to negatively regulate growth, since blockade of WNK1 phosphorylation increased the effect of insulin on preadipocyte cell division [119]. The ability of WNK1 mRNA to rescue the effects of VEGF2R knock-down in Zebrafish also relies on an intact $\mathrm{Akt} / \mathrm{PKB} 1$ sequence to allow $\mathrm{Thr}^{60}$ phosphorylation. Akt/PKB1 activation of WNK1 in the kidney is also seen in $\mathrm{db} / \mathrm{db}$ mice suggesting it has a role in the hypertension seen in the metabolic syndrome [120].

\section{VEGF/WNK signalling and hypertension}

Could the interplay of VEGFR2 and WNK1 signalling pathways have a role in regulating blood pressure outside of the embryonic vasculature? The widespread use of inhibitors of VEGF in oncotherapy, both in the form of monoclonal antibodies to block VEGF receptors or small molecule inhibitors of VEGF TK receptor signalling has highlighted a high frequency of hypertension as a side effect [121]. In trials, the majority of patients actually develop hypertension especially those involving potent VEGF TK inhibitors such as axitinib [122]. The severity of the hypertension parallels the level of functional VEGF inhibition and is reversed when the inhibitor is stopped. Hence, an off-target effect seems unlikely and the degree of hypertension may even be a biomarker of a favourable treatment response. Nevertheless, the molecular mechanisms behind this pressor effect are still unclear. Endothelial dysfunction, vascular stiffening or remodelling and vascular rarefaction (a reduction in the density of microvessels) have all been suggested [121]. The hypothesis of rarefaction is perhaps the most suggestive of a mechanism reflecting VEGF/WNK signalling cross-talk. However, this has not been explored, but is attractive as the rarefaction may be blocked by drugs targeting the WNK/ SPAK/OSR1 cascade (see "WNK/SPAK/OSR as a druggable signalling pathway").

\section{WNK/SPAK/OSR as a druggable signalling pathway}

The conserved carboxy-terminal (CCT) domain of SPAK binds with high affinity to RFXV/I motifs that are present both in its upstream activator (WNKs) as well as its downstream substrates (Fig. 3). In fact, mutation of a single highly conserved Leu502 within the CCT domain abolishes high affinity binding to the RFXI/V motif. The critical importance of SPAK docking to its binding partners for WNK/SPAK/OSR signalling was confirmed by mutation of the canonical Leu50 to alanine [44]. Mice homozygous for this mutation show marked reduction in expression and phosphorylation of NCC and NKCC 2 in the kidney. The mice were also hypotensive suggesting that blocking the CCT domain with a small molecule could provide a novel antihypertensive strategy.

To identify lead compounds that block binding to the CCT domain of SPAK, Uchida's group developed a highthroughput assay using a fluorescent RFXV/I peptide based on the motif present in either WNK1 or WNK4 as bate for a GSK-SPAK-CCT fusion protein [89]. The bait-target interaction was assessed by fluorescent correlation spectroscopy. Using this approach, they were able to identify ten candidate molecules from a 17,000 compound library with STOCK1S-50699 (PubChem-CID 5749625) and STOCK2S-26016 (PubChem-CID 3135086) having the highest activity. These two molecules were also able to block phosphorylation of SPAK and NCC in a cell-based assay. The same group also developed a second highthroughput assay employing a novel ELISA-based assay to detect inhibition of NKCC2 phosphorylation [123]. Using an extended library (totalling almost 22,000 compounds) they identified a single lead molecule (1S-14279; PubChem CID 01676700) that in the Biacore ${ }^{\circledR}$ system bound to SPAK with an affinity constant of $\sim 10^{5} \mathrm{M}^{-1}$. Further work showed that the molecule was chemically similar to another molecule detected with the assay run against another smaller targeted library. This molecule was closantel, a known anthelminthic drug. Both closantel and 1S-14279 appeared to block SPAK docking to it phosphorylation target rather than compete with ATP binding. This is important for specificity of these molecules given 
the structural similarity of the ATP binding site throughout the family of TK proteins.

In cell-based assays, closantel and 1S-14279 were both effective at blocking NCC phosphorylation [123]. They also acutely reduced the level of phosphoNCC and phosphoNKCC1 in vivo. However, 1S-14279 appears too toxic for chronic administration and closantel, while reducing levels of phosphoproteins very significantly over 7-day administration had no effect on blood pressure or serum or urinary electrolytes. However, another very promising lead molecule has emerged very recently in the form of a substituted imidazole WNK463 [124]. This compound is able to block all of the WNKs (WNK1, WNK2, WNK3 and WNK4) in vitro in the $\mathrm{nM}$ concentration range. It is also orally active and reduced BP, urinary $\mathrm{Na}^{+}$output and phosphorylation levels of WNK4 in mouse kidney lysates. However, it has not been developed further as a therapeutic agent due to problems with its preclinical safety profile. Nevertheless, WNK463 will be an invaluable tool molecule and provides a clear proof of principle that targeting the WNK/SPAK/OSR1 cascade can provide effective antihypertensive drugs for clinical use.

\section{Conclusion}

The WNKs are ancient proteins in evolutionary terms and were co-opted early on to control cell volume and intracellular chloride levels by forming signalling pathways with the related kinases, SPAK and OSR1. In transporting epithelium, including the kidney nephron itself these pathways are crucial to the regulation of ion fluxes by controlling the phosphorylation state of key membrane transporters. Hence, the WNK/SPAK/OSR1 signalling pathway directly influences blood pressure, as is clearly seen in rare monogenic blood pressure syndromes mutating single genes in the cascade. Emerging evidence suggests that WNK/SPAK/OSR1 signalling also operates outside of the kidney where it is able to regulate blood vessel tone directly. Much is still to be learned about the physiology and pathophysiology of the WNKs and their signalling roles, but targeting the WNK/SPAK/NCC pathway holds considerable promise for the development of novel antihypertensive drugs and diuretics.

Acknowledgements $\mathrm{KMO}$ and MM would like to thank the British Heart Foundation for support in some of their work cited in this review $(\mathrm{PG} / 13 / 89 / 30577)$.

Open Access This article is distributed under the terms of the Creative Commons Attribution 4.0 International License (http:// creativecommons.org/licenses/by/4.0/), which permits unrestricted use, distribution, and reproduction in any medium, provided you give appropriate credit to the original author(s) and the source, provide a link to the Creative Commons license, and indicate if changes were made.

\section{References}

1. Narayan KM, Ali MK, Koplan JP (2010) Global noncommunicable diseases-where worlds meet. $\mathrm{N}$ Engl $\mathrm{J}$ Med 363(13):1196-1198. doi:10.1056/NEJMp1002024

2. Guyton AC (1991) Blood pressure control—special role of the kidneys and body fluids. Science 252(5014):1813-1816

3. Paver WK, Pauline GJ (1964) Hypertension and hyperpotassaemia without renal disease in a young male. Med J Aust 2:305-306

4. Mayan H, Vered I, Mouallem M, Tzadok-Witkon M, Pauzner R, Farfel Z (2002) Pseudohypoaldosteronism type II: marked sensitivity to thiazides, hypercalciuria, normomagnesemia, and low bone mineral density. J Clin Endocrinol Metab 87(7):3248-3254. doi:10.1210/jcem.87.7.8449

5. Simon DB, Nelson-Williams C, Bia MJ, Ellison D, Karet FE, Molina AM, Vaara I, Iwata F, Cushner HM, Koolen M, Gainza FJ, Gitleman HJ, Lifton RP (1996) Gitelman's variant of Bartter's syndrome, inherited hypokalemic alkalosis, is caused by mutations in the thiazide-sensitive $\mathrm{Na}-\mathrm{Cl}$ cotransporter. Nat Genet 12(1):24-30. doi:10.1038/ng0196-24

6. Manning G, Whyte DB, Martinez R, Hunter T, Sudarsanam S (2002) The protein kinase complement of the human genome. Science 298(5600):1912-1934. doi:10.1126/science.1075762

7. Piala AT, Moon TM, Akella R, He H, Cobb MH, Goldsmith EJ (2014) Chloride sensing by WNK1 kinase involves inhibition of autophosphorylation. Sci Signal 7 (324):ra41. doi:10.1126/ scisignal.2005050

8. Lenertz LY, Lee B-H, Min X, B-e Xu, Wedin K, Earnest S, Goldsmith EJ, Cobb MH (2005) Properties of WNK1 and implications for other family members. J Biol Chem 280(29):26653-26658. doi:10.1074/jbc.M502598200

9. Richardson C, Alessi DR (2008) The regulation of salt transport and blood pressure by the WNK-SPAK/OSR1 signalling pathway. J Cell Sci 121(Pt 20):3293-3304. doi:10.1242/jcs.029223

10. Zagórska A, Pozo-Guisado E, Boudeau J, Vitari AC, Rafiqi FH, Thastrup J, Deak M, Campbell DG, Morrice NA, Prescott AR, Alessi DR (2007) Regulation of activity and localization of the WNK1 protein kinase by hyperosmotic stress. J Cell Biol 176(1):89-100. doi:10.1083/jcb.200605093

11. Haas M, Forbush B 3rd (2000) The Na-K-Cl cotransporter of secretory epithelia. Annu Rev Physiol 62:515-534. doi:10.1146/ annurev.physiol.62.1.515

12. Kahle KT, Rinehart J, Lifton RP (2010) Phosphoregulation of the $\mathrm{Na}-\mathrm{K}-2 \mathrm{Cl}$ and $\mathrm{K}-\mathrm{Cl}$ cotransporters by the WNK kinases. Biochim Biophys Acta 1802(12):1150-1158. doi:10.1016/j. bbadis.2010.07.009

13. B-e Xu, English JM, Wilsbacher JL, Stippec S, Goldsmith EJ, Cobb MH (2000) WNK1, a novel mammalian serine/threonine protein kinase lacking the catalytic lysine in subdomain II. J Biol Chem 275(22):16795-16801. doi:10.1074/jbc.275.22. 16795

14. Wilson FH, Disse-Nicodeme S, Choate KA, Ishikawa K, Nelson-Williams C, Desitter I, Gunel M, Milford DV, Lipkin GW, Achard JM, Feely MP, Dussol B, Berland Y, Unwin RJ, Mayan H, Simon DB, Farfel Z, Jeunemaitre X, Lifton RP (2001) Human hypertension caused by mutations in WNK kinases. Science 293(5532):1107-1112. doi:10.1126/science.1062844

15. Boyden LM, Choi M, Choate KA, Nelson-Williams CJ, Farhi A, Toka HR, Tikhonova IR, Bjornson R, Mane SM, Colussi G, Lebel M, Gordon RD, Semmekrot BA, Poujol A, Valimaki MJ, De Ferrari ME, Sanjad SA, Gutkin M, Karet FE, Tucci JR, Stockigt JR, Keppler-Noreuil KM, Porter CC, Anand SK, Whiteford ML, Davis ID, Dewar SB, Bettinelli A, Fadrowski JJ, Belsha CW, Hunley TE, Nelson RD, Trachtman H, Cole TR, 
Pinsk M, Bockenhauer D, Shenoy M, Vaidyanathan P, Foreman JW, Rasoulpour M, Thameem F, Al-Shahrouri HZ, Radhakrishnan J, Gharavi AG, Goilav B, Lifton RP (2012) Mutations in kelch-like 3 and cullin 3 cause hypertension and electrolyte abnormalities. Nature 482(7383):98-102. doi:10.1038/ nature 10814

16. Schumacher FR, Siew K, Zhang J, Johnson C, Wood N, Cleary SE, Al Maskari RS, Ferryman JT, Hardege I, Yasmin Figg NL, Enchev R, Knebel A, O'Shaughnessy KM, Kurz T (2015) Characterisation of the cullin-3 mutation that causes a severe form of familial hypertension and hyperkalemia. EMBO Mol Med 7(10):1285-1306. doi:10.15252/emmm.201505444

17. Ohta A, Schumacher FR, Mehellou Y, Johnson C, Knebel A, Macartney TJ, Wood NT, Alessi DR, Kurz T (2013) The cul3klhl3 e3 ligase complex mutated in Gordon's hypertension syndrome interacts with and ubiquitylates WNK isoforms: disease-causing mutations in KLHL3 and WNK4 disrupt interaction. Biochem J 451(1):111-122. doi:10.1042/ bj20121903

18. Louis-Dit-Picard H, Barc J, Trujillano D, Miserey-Lenkei S, Bouatia-Naji N, Pylypenko O, Beaurain G, Bonnefond A, Sand O, Simian C, Vidal-Petiot E, Soukaseum C, Mandet C, Broux F, Chabre O, Delahousse M, Esnault V, Fiquet B, Houillier P, Bagnis CI, Koenig J, Konrad M, Landais P, Mourani C, Niaudet P, Probst V, Thauvin C, Unwin RJ, Soroka SD, Ehret G, Ossowski S, Caulfield M, International Consortium for Blood P, Bruneval P, Estivill X, Froguel P, Hadchouel J, Schott JJ, Jeunemaitre X (2012) KLHL3 mutations cause familial hyperkalemic hypertension by impairing ion transport in the distal nephron. Nat Genet 44 (4):456-460 (S451-S453). doi:10.1038/ ng. 2218

19. Kahle KT, Wilson FH, Leng Q, Lalioti MD, O'Connell AD, Dong K, Rapson AK, MacGregor GG, Giebisch G, Hebert SC, Lifton RP (2003) WNK4 regulates the balance between renal $\mathrm{NaCl}$ reabsorption and $\mathrm{K}+$ secretion. Nat Genet 35(4):372-376. doi:10.1038/ng1271

20. Kahle KT, Macgregor GG, Wilson FH, Van Hoek AN, Brown D, Ardito T, Kashgarian M, Giebisch G, Hebert SC, Boulpaep EL, Lifton RP (2004) Paracellular Cl- permeability is regulated by WNK4 kinase: insight into normal physiology and hypertension. Proc Natl Acad Sci USA 101(41):14877-14882. doi:10. 1073/pnas.0406172101

21. Melo Z, Cruz-Rangel S, Bautista R, Vazquez N, CastanedaBueno M, Mount DB, Pasantes-Morales H, Mercado A, Gamba $\mathrm{G}$ (2013) Molecular evidence for a role for $\mathrm{K}(+)-\mathrm{Cl}(-)$ cotransporters in the kidney. Am J Physiol Renal Physiol 305(10):F1402-F1411. doi:10.1152/ajprenal.00390.2013

22. Yang CL, Angell J, Mitchell R, Ellison DH (2003) WNK kinases regulate thiazide-sensitive $\mathrm{Na}-\mathrm{Cl}$ cotransport. J Clin Invest 111(7):1039-1045

23. Leng Q, Kahle KT, Rinehart J, MacGregor GG, Wilson FH, Canessa CM, Lifton RP, Hebert SC (2006) WNK3, a kinase related to genes mutated in hereditary hypertension with hyperkalaemia, regulates the $\mathrm{K}+$ channel ROMK1 (kir1.1). J Physiol 571 (Pt 2):275-286. doi:10.1113/jphysiol.2005.102202

24. Naray-Fejes-Toth A, Snyder PM, Fejes-Toth G (2004) The kidney-specific WNK1 isoform is induced by aldosterone and stimulates epithelial sodium channel-mediated $\mathrm{Na}+$ transport. Proc Natl Acad Sci USA 101(50):17434-17439. doi:10.1073/ pnas.0408146101

25. Vidal-Petiot E, Elvira-Matelot E, Mutig K, Soukaseum C, Baudrie V, Wu S, Cheval L, Huc E, Cambillau M, Bachmann S, Doucet A, Jeunemaitre X, Hadchouel J (2013) WNK1-related familial hyperkalemic hypertension results from an increased expression of 1-WNK1 specifically in the distal nephron. Proc
Natl Acad Sci USA 110(35):14366-14371. doi:10.1073/pnas. 1304230110

26. Lifton RP, Gharavi AG, Geller DS (2001) Molecular mechanisms of human hypertension. Cell 104(4):545-556

27. Na T, Wu G, Zhang W, Dong WJ, Peng JB (2013) Diseasecausing $\mathrm{r} 1185 \mathrm{c}$ mutation of WNK4 disrupts a regulatory mechanism involving calmodulin binding and SGK1 phosphorylation sites. Am J Physiol Renal Physiol 304(1):F8-F18. doi:10.1152/ajprenal.00284.2012

28. Arroyo JP, Kahle KT, Gamba G (2013) The slc12 family of electroneutral cation-coupled chloride cotransporters. Mol Aspects Med 34(2-3):288-298. doi:10.1016/j.mam.2012.05.002

29. Gamba G (2005) Molecular physiology and pathophysiology of electroneutral cation-chloride cotransporters. Physiol Rev 85(2):423-493. doi:10.1152/physrev.00011.2004

30. Strange K, Denton J, Nehrke K (2006) Ste20-type kinases: evolutionarily conserved regulators of ion transport and cell volume. Physiology (Bethesda) 21:61-68. doi:10.1152/physiol. 00139.2005

31. Delaloy C, Lu J, Houot AM, Disse-Nicodeme S, Gasc JM, Corvol P, Jeunemaitre X (2003) Multiple promoters in the WNK1 gene: one controls expression of a kidney-specific kinase-defective isoform. Mol Cell Biol 23(24):9208-9221

32. O'Reilly M, Marshall E, Speirs HJ, Brown RW (2003) WNK1, a gene within a novel blood pressure control pathway, tissuespecifically generates radically different isoforms with and without a kinase domain. J Am Soc Nephrol 14(10):2447-2456

33. Wilson FH, Kahle KT, Sabath E, Lalioti MD, Rapson AK, Hoover RS, Hebert SC, Gamba G, Lifton RP (2003) Molecular pathogenesis of inherited hypertension with hyperkalemia: the $\mathrm{Na}-\mathrm{Cl}$ cotransporter is inhibited by wild-type but not mutant WNK4. Proc Natl Acad Sci USA 100(2):680-684. doi:10.1073/ pnas.242735399

34. Yang CL, Angell J, Mitchell R, Ellison DH (2003) Wnk kinases regulate thiazide-sensitive $\mathrm{Na}-\mathrm{Cl}$ cotransport. J Clin Invest 111(7):1039-1045. doi:10.1172/jci17443

35. Vitari AC, Deak M, Morrice NA, Alessi DR (2005) The WNK1 and WNK4 protein kinases that are mutated in Gordon's hypertension syndrome phosphorylate and activate SPAK and OSR1 protein kinases. Biochem J 391(Pt 1):17-24. doi:10.1042/ BJ20051180

36. Gagnon KB, Delpire E (2012) Molecular physiology of SPAK and OSR1: two ste20-related protein kinases regulating ion transport. Physiol Rev 92(4):1577-1617. doi:10.1152/physrev. 00009.2012

37. Piechotta K, Garbarini N, England R, Delpire E (2003) Characterization of the interaction of the stress kinase SPAK with the $\mathrm{Na}+-\mathrm{K}+-2 \mathrm{Cl}-$ cotransporter in the nervous system: evidence for a scaffolding role of the kinase. J Biol Chem 278(52):52848-52856. doi:10.1074/jbc.M309436200

38. Rafiqi FH, Zuber AM, Glover M, Richardson C, Fleming S, Jovanovic S, Jovanovic A, O'Shaughnessy KM, Alessi DR (2010) Role of the WNK-activated SPAK kinase in regulating blood pressure. EMBO Mol Med 2(2):63-75. doi:10.1002/ emmm.200900058

39. McCormick JA, Mutig K, Nelson JH, Saritas T, Hoorn EJ, Yang CL, Rogers S, Curry J, Delpire E, Bachmann S, Ellison DH (2011) A SPAK isoform switch modulates renal salt transport and blood pressure. Cell Metab 14(3):352-364. doi:10.1016/j. cmet.2011.07.009

40. Rinehart J, Vazquez N, Kahle KT, Hodson CA, Ring AM, Gulcicek EE, Louvi A, Bobadilla NA, Gamba G, Lifton RP (2011) WNK2 kinase is a novel regulator of essential neuronal cation-chloride cotransporters. J Biol Chem 286(34):30171-30180. doi:10.1074/jbc.M111.222893 
41. Filippi BM, de los Heros P, Mehellou Y, Navratilova I, Gourlay R, Deak M, Plater L, Toth R, Zeqiraj E, Alessi DR (2011) Mo25 is a master regulator of SPAK/OSR1 and MST3/MST4/YSK1 protein kinases. EMBO J 30 (9):1730-1741. doi:10.1038/emboj. 2011.78

42. Vitari AC, Thastrup J, Rafiqi FH, Deak M, Morrice NA, Karlsson HK, Alessi DR (2006) Functional interactions of the SPAK/OSR1 kinases with their upstream activator WNK1 and downstream substrate NKCC1. Biochem J 397(1):223-231. doi:10.1042/bj20060220

43. Villa F, Goebel J, Rafiqi FH, Deak M, Thastrup J, Alessi DR, van Aalten DM (2007) Structural insights into the recognition of substrates and activators by the OSR1 kinase. EMBO Rep 8(9):839-845. doi:10.1038/sj.embor.7401048

44. Zhang J, Siew K, Macartney T, O’Shaughnessy KM, Alessi DR (2015) Critical role of the SPAK protein kinase CCT domain in controlling blood pressure. Hum Mol Genet 24(16):4545-4558. doi: $10.1093 / \mathrm{hmg} / \mathrm{ddv} 185$

45. Richardson C, Rafiqi FH, Karlsson HK, Moleleki N, Vandewalle A, Campbell DG, Morrice NA, Alessi DR (2008) Activation of the thiazide-sensitive $\mathrm{Na}+-\mathrm{Cl}-$ cotransporter by the WNK-regulated kinases SPAK and OSR1. J Cell Sci 121(Pt 5):675-684. doi:10.1242/jcs.025312

46. Yang SS, Lo YF, Wu CC, Lin SW, Yeh CJ, Chu P, Sytwu HK, Uchida S, Sasaki S, Lin SH (2010) SPAK-knockout mice manifest Gitelman syndrome and impaired vasoconstriction. J Am Soc Nephrol 21(11):1868-1877. doi:10.1681/asn. 2009121295

47. Lin SH, Yu IS, Jiang ST, Lin SW, Chu P, Chen A, Sytwu HK, Sohara E, Uchida S, Sasaki S, Yang SS (2011) Impaired phosphorylation of $\mathrm{Na}(+)-\mathrm{K}(+)-2 \mathrm{Cl}(-)$ cotransporter by oxidative stress-responsive kinase-1 deficiency manifests hypotension and Bartter-like syndrome. Proc Natl Acad Sci USA 108(42):17538-17543. doi:10.1073/pnas.1107452108

48. Xie J, Yoon J, Yang SS, Lin SH, Huang CL (2013) WNK1 protein kinase regulates embryonic cardiovascular development through the OSR1 signaling cascade. J Biol Chem 288(12):8566-8574. doi:10.1074/jbc.M113.451575

49. Ferdaus MZ, Barber KW, Lopez-Cayuqueo KI, Terker AS, Argaiz ER, Gassaway BM, Chambrey R, Gamba G, Rinehart J, McCormick JA (2016) SPAK and OSR1 play essential roles in potassium homeostasis through actions on the distal convoluted tubule. J Physiol 594(17):4945-4966. doi:10.1113/jp272311

50. Tragante V, Barnes Michael R, Ganesh Santhi K, Lanktree Matthew B, Guo W, Franceschini N, Smith Erin N, Johnson T, Holmes Michael V, Padmanabhan S, Karczewski Konrad J, Almoguera B, Barnard J, Baumert J, Chang Y-Pei C, Elbers Clara C, Farrall M, Fischer Mary E, Gaunt Tom R, Gho Johannes M, Gieger C, Goel A, Gong Y, Isaacs A, Kleber Marcus E, Leach Irene M, McDonough Caitrin W, Meijs Matthijs F, Melander O, Nelson Christopher P, Nolte Ilja M, Pankratz N, Price Tom S, Shaffer J, Shah S, Tomaszewski M, van der Most Peter J, Van Iperen Erik P, Vonk Judith M, Witkowska K, Wong Caroline O, Zhang L, Beitelshees Amber L, Berenson Gerald S, Bhatt Deepak L, Brown M, Burt A, CooperDeHoff Rhonda M, Connell John M, Cruickshanks Karen J, Curtis Sean P, Davey-Smith G, Delles C, Gansevoort Ron T, Guo X, Haiqing S, Hastie Claire E, Hofker Marten H, Hovingh G K, Kim Daniel S, Kirkland Susan A, Klein Barbara E, Klein R, Li Yun R, Maiwald S, Newton-Cheh C, O'Brien Eoin T, Onland-Moret N C, Palmas W, Parsa A, Penninx Brenda W, Pettinger M, Vasan RS, Ranchalis Jane E, M Ridker P, Rose Lynda M, Sever P, Shimbo D, Steele L, Stolk Ronald P, Thorand B, Trip Mieke D, van Duijn Cornelia M, Verschuren W M, Wijmenga C, Wyatt S, Young J H, Zwinderman Aeilko H, Bezzina Connie R, Boerwinkle E, Casas Juan P, Caulfield
Mark J, Chakravarti A, Chasman Daniel I, Davidson Karina W, Doevendans Pieter A, Dominiczak Anna F, FitzGerald Garret A, Gums John G, Fornage M, Hakonarson H, Halder I, Hillege Hans L, Illig T, Jarvik Gail P, Johnson Julie A, Kastelein John J, Koenig W, Kumari M, März W, Murray Sarah S, O'Connell Jeffery R, Oldehinkel Albertine J, Pankow James S, Rader Daniel J, Redline S, Reilly Muredach P, Schadt Eric E, Kottke-Marchant K, Snieder H, Snyder M, Stanton Alice V, Tobin Martin D, Uitterlinden André G, van der Harst P, van der Schouw Yvonne T, Samani Nilesh J, Watkins H, Johnson Andrew D, Reiner Alex P, Zhu X, de Bakker Paul I, Levy D, Asselbergs Folkert W, Munroe Patricia B, Keating Brendan J (2014) Gene-centric meta-analysis in 87,736 individuals of european ancestry identifies multiple blood-pressure-related loci. Am J Hum Genet 94 (3):349-360. doi:10.1016/j.ajhg.2013. 12.016

51. Munroe PB, Barnes MR, Caulfield MJ (2013) Advances in blood pressure genomics. Circ Res 112(10):1365-1379. doi:10. 1161/circresaha.112.300387

52. Wang Y, O'Connell JR, McArdle PF, Wade JB, Dorff SE, Shah SJ, Shi X, Pan L, Rampersaud E, Shen H, Kim JD, Subramanya AR, Steinle NI, Parsa A, Ober CC, Welling PA, Chakravarti A, Weder AB, Cooper RS, Mitchell BD, Shuldiner AR, Chang Y-PC (2009) Whole-genome association study identifies stk39 as a hypertension susceptibility gene. Proc Natl Acad Sci USA 106(1):226-231. doi:10.1073/pnas.0808358106

53. Kidambi S, Ghosh S, Kotchen JM, Grim CE, Krishnaswami S, Kaldunski ML, Cowley AW, Patel SB, Kotchen TA (2012) Nonreplication study of a genome-wide association study for hypertension and blood pressure in African Americans. BMC Med Genet 13:27. doi:10.1186/1471-2350-13-27

54. Xi B, Zhao X, Chandak GR, Shen Y, Cheng H, Hou D, Wang X, Mi J (2013) Influence of obesity on association between genetic variants identified by genome-wide association studies and hypertension risk in chinese children. Am J Hypertens 26(8):990-996. doi:10.1093/ajh/hpt046

55. Xi B, Chen M, Chandak GR, Shen Y, Yan L, He J, Mou S-H (2013) Stk39 polymorphism is associated with essential hypertension: a systematic review and meta-analysis. PLoS One 8(3):e59584. doi:10.1371/journal.pone.0059584

56. Zhao H, Qi Y, Wang Y, Wang Y, Lu C, Xiao Y, Wang B, Niu W (2014) Interactive contribution of serine/threonine kinase 39 gene multiple polymorphisms to hypertension among northeastern Han Chinese. Sci Rep 4:5116. doi:10.1038/srep05116

57. Shao L, Lang Y, Wang Y, Gao Y, Zhang W, Niu H, Liu S, Chen $\mathrm{N}$ (2012) High-frequency variant $\mathrm{p}$. T60m in $\mathrm{NaCl}$ cotransporter and blood pressure variability in Han Chinese. Am J Nephrol 35(6):515-519. doi:10.1159/000339165

58. Yang S-S, Fang Y-W, Tseng M-H, Chu P-Y, Yu I-S, Wu H-C, Lin S-W, Chau T, Uchida S, Sasaki S, Lin Y-F, Sytwu H-K, Lin S-H (2013) Phosphorylation regulates NCC stability and transporter activity in vivo. J Am Soc Nephrol 24(10):1587-1597. doi:10.1681/asn.2012070742

59. Yang CL, Zhu X, Wang Z, Subramanya AR, Ellison DH (2005) Mechanisms of WNK1 and WNK4 interaction in the regulation of thiazide-sensitive nacl cotransport. $J$ Clin Invest 115(5):1379-1387. doi:10.1172/jci22452

60. Ellison DH (2003) The thiazide-sensitive $\mathrm{Na}-\mathrm{Cl}$ cotransporter and human disease: reemergence of an old player. J Am Soc Nephrol 14(2):538-540

61. Moriguchi T, Urushiyama S, Hisamoto N, Iemura S, Uchida S, Natsume T, Matsumoto K, Shibuya H (2005) WNK1 regulates phosphorylation of cation-chloride-coupled cotransporters via the ste20-related kinases, SPAK and OSR1. J Biol Chem 280(52):42685-42693. doi:10.1074/jbc.M510042200 
62. Xie J, Wu T, Xu K, Huang IK, Cleaver O, Huang C-L (2009) Endothelial-specific expression of WNK1 kinase is essential for angiogenesis and heart development in mice. Am J Pathol 175(3):1315-1327. doi:10.2353/ajpath.2009.090094

63. Zambrowicz BP, Abuin A, Ramirez-Solis R, Richter LJ, Piggott J, BeltrandelRio H, Buxton EC, Edwards J, Finch RA, Friddle CJ, Gupta A, Hansen G, Hu Y, Huang W, Jaing C, Key BW, Kipp P, Kohlhauff B, Ma Z-Q, Markesich D, Payne R, Potter DG, Qian N, Shaw J, Schrick J, Shi Z-Z, Sparks MJ, Van Sligtenhorst I, Vogel P, Walke W, Xu N, Zhu Q, Person C, Sands AT (2003) WNK1 kinase deficiency lowers blood pressure in mice: a gene-trap screen to identify potential targets for therapeutic intervention. Proc Natl Acad Sci 100(24):14109-14114. doi:10.1073/pnas.2336103100

64. Pacheco-Alvarez D, Vazquez N, Castaneda-Bueno M, de-LosHeros P, Cortes-Gonzalez C, Moreno E, Meade P, Bobadilla NA, Gamba G (2012) WNK3-SPAK interaction is required for the modulation of NCC and other members of the slc12 family. Cell Physiol Biochem 29 (1-2):291-302. doi:10.1159/ 000337610

65. Rinehart J, Kahle KT, de Los Heros P, Vazquez N, Meade P, Wilson FH, Hebert SC, Gimenez I, Gamba G, Lifton RP (2005) WNK3 kinase is a positive regulator of NKCC2 and NCC, renal cation- $\mathrm{Cl}-$ cotransporters required for normal blood pressure homeostasis. Proc Natl Acad Sci USA 102(46):16777-16782. doi:10.1073/pnas.0508303102

66. Glover M, Zuber AM, O'Shaughnessy KM (2009) Renal and brain isoforms of WNK3 have opposite effects on NCCT expression. J Am Soc Nephrol 20(6):1314-1322. doi:10.1681/ asn.2008050542

67. Oi K, Sohara E, Rai T, Misawa M, Chiga M, Alessi DR, Sasaki S, Uchida S (2012) A minor role of WNK3 in regulating phosphorylation of renal NKCC2 and NCC co-transporters in vivo. Biol Open 1(2):120-127. doi:10.1242/bio.2011048

68. Bazua-Valenti S, Chavez-Canales M, Rojas-Vega L, GonzalezRodriguez X, Vazquez N, Rodriguez-Gama A, Argaiz ER, Melo Z, Plata C, Ellison DH, Garcia-Valdes J, Hadchouel J, Gamba G (2015) The effect of WNK4 on the $\mathrm{Na}+-\mathrm{Cl}-$ cotransporter is modulated by intracellular chloride. J Am Soc Nephrol 26(8):1781-1786. doi:10.1681/asn.2014050470

69. Gamba G (2012) Regulation of the renal $\mathrm{Na}+-\mathrm{Cl}-$ cotransporter by phosphorylation and ubiquitylation. Am J Physiol Renal Physiol 303(12):F1573-F1583. doi:10.1152/ajprenal. 00508.2012

70. Castaneda-Bueno M, Cervantes-Perez LG, Vazquez N, Uribe N, Kantesaria S, Morla L, Bobadilla NA, Doucet A, Alessi DR, Gamba G (2012) Activation of the renal $\mathrm{Na}+\mathrm{Cl}-$ cotransporter by angiotensin II is a WNK4-dependent process. Proc Natl Acad Sci USA 109(20):7929-7934. doi:10.1073/pnas.1200947109

71. Lalioti MD, Zhang J, Volkman HM, Kahle KT, Hoffmann KE, Toka HR, Nelson-Williams C, Ellison DH, Flavell R, Booth CJ, Lu Y, Geller DS, Lifton RP (2006) WNK4 controls blood pressure and potassium homeostasis via regulation of mass and activity of the distal convoluted tubule. Nat Genet 38(10):1124-1132. doi:10.1038/ng1877

72. Terker AS, Zhang C, Erspamer KJ, Gamba G, Yang CL, Ellison DH (2016) Unique chloride-sensing properties of WNK4 permit the distal nephron to modulate potassium homeostasis. Kidney Int 89(1):127-134. doi:10.1038/ki.2015.289

73. Penton D, Czogalla J, Wengi A, Himmerkus N, Loffing-Cueni D, Carrel M, Rajaram RD, Staub O, Bleich M, Schweda F, Loffing J (2016) Extracellular K+ rapidly controls NCC phosphorylation in native DCT by $\mathrm{Cl}-$-dependent and -independent mechanisms. J Physiol. doi:10.1113/jp272504

74. Weinstein AM (2005) A mathematical model of rat distal convoluted tubule. I. Cotransporter function in early DCT. Am J
Physiol Renal Physiol 289(4):F699-F720. doi:10.1152/ajprenal. 00043.2005

75. Hadchouel J, Delaloy C, Faure S, Achard JM, Jeunemaitre X (2006) Familial hyperkalemic hypertension. J Am Soc Nephrol 17(1):208-217. doi:10.1681/asn.2005030314

76. Genschik P, Sumara I, Lechner E (2013) The emerging family of cullin3-ring ubiquitin ligases (crl3s): cellular functions and disease implications. EMBO J 32(17):2307-2320. doi:10.1038/ emboj.2013.173

77. Petroski MD, Deshaies RJ (2005) Function and regulation of cullin-ring ubiquitin ligases. Nat Rev Mol Cell Biol 6(1):9-20. doi:10.1038/nrm1547

78. Hershko A, Ciechanover A (1998) The ubiquitin system. Annu Rev Biochem 67:425-479. doi:10.1146/annurev.biochem.67.1.425

79. Zheng N, Schulman BA, Song L, Miller JJ, Jeffrey PD, Wang P, Chu C, Koepp DM, Elledge SJ, Pagano M, Conaway RC, Conaway JW, Harper JW, Pavletich NP (2002) Structure of the cul1-rbx1-skp1-f boxskp2 scf ubiquitin ligase complex. Nature 416(6882):703-709. doi:10.1038/416703a

80. Dhanoa BS, Cogliati T, Satish AG, Bruford EA, Friedman JS (2013) Update on the kelch-like (klhl) gene family. Hum Genom 7:13. doi:10.1186/1479-7364-7-13

81. Wakabayashi M, Mori T, Isobe K, Sohara E, Susa K, Araki Y, Chiga M, Kikuchi E, Nomura N, Mori Y, Matsuo H, Murata T, Nomura S, Asano T, Kawaguchi H, Nonoyama S, Rai T, Sasaki S, Uchida S (2013) Impaired KLHL3-mediated ubiquitination of WNK4 causes human hypertension. Cell Rep 3(3):858-868. doi:10.1016/j.celrep.2013.02.024

82. Shibata S, Zhang J, Puthumana J, Stone KL, Lifton RP (2013) Kelch-like 3 and cullin 3 regulate electrolyte homeostasis via ubiquitination and degradation of WNK4. Proc Natl Acad Sci USA 110(19):7838-7843. doi:10.1073/pnas.1304592110

83. Susa K, Sohara E, Rai T, Zeniya M, Mori Y, Mori T, Chiga M, Nomura N, Nishida H, Takahashi D, Isobe K, Inoue Y, Takeishi K, Takeda N, Sasaki S, Uchida S (2014) Impaired degradation of WNK1 and WNK4 kinases causes PHAII in mutant KLHL3 knock-in mice. Hum Mol Genet 23(19):5052-5060. doi:10. 1093/hmg/ddu217

84. Osawa M, Ogura Y, Isobe K, Uchida S, Nonoyama S, Kawaguchi $\mathrm{H}$ (2013) Cul3 gene analysis enables early intervention for pediatric pseudohypoaldosteronism type II in infancy. Pediatr Nephrol 28(9):1881-1884. doi:10.1007/s00467-013-2496-6

85. Tsuji S, Yamashita M, Unishi G, Takewa R, Kimata T, Isobe K, Chiga M, Uchida S, Kaneko K (2013) A young child with pseudohypoaldosteronism type II by a mutation of cullin 3 . BMC Nephrol 14:166. doi:10.1186/1471-2369-14-166

86. McCormick JA, Yang CL, Zhang C, Davidge B, Blankenstein KI, Terker AS, Yarbrough B, Meermeier NP, Park HJ, McCully B, West M, Borschewski A, Himmerkus N, Bleich M, Bachmann S, Mutig K, Argaiz ER, Gamba G, Singer JD, Ellison DH (2014) Hyperkalemic hypertension-associated cullin 3 promotes WNK signaling by degrading KLHL3. J Clin Invest 124(11):4723-4736. doi:10.1172/JCI76126

87. Yang SS, Morimoto T, Rai T, Chiga M, Sohara E, Ohno M, Uchida K, Lin SH, Moriguchi T, Shibuya H, Kondo Y, Sasaki S, Uchida S (2007) Molecular pathogenesis of pseudohypoaldosteronism type II: generation and analysis of a WNK4(d561a/+) knockin mouse model. Cell Metab 5(5):331-344. doi:10.1016/j. cmet.2007.03.009

88. Chowdhury JA, Liu CH, Zuber AM, O’Shaughnessy KM (2013) An inducible transgenic mouse model for familial hypertension with hyperkalemia (Gordon's syndrome or pseudohypoaldosteronism type II). Clin Sci (Lond) 124(12):701-708. doi:10. $1042 / \operatorname{cs} 20120430$

89. Mori T, Kikuchi E, Watanabe Y, Fujii S, Ishigami-Yuasa M, Kagechika H, Sohara E, Rai T, Sasaki S, Uchida S (2013) 
Chemical library screening for WNK signalling inhibitors using fluorescence correlation spectroscopy. Biochem J 455(3):339-345. doi:10.1042/bj20130597

90. Barroso I, Gurnell M, Crowley VE, Agostini M, Schwabe JW, Soos MA, Maslen GL, Williams TD, Lewis H, Schafer AJ, Chatterjee VK, O'Rahilly S (1999) Dominant negative mutations in human PPARgamma associated with severe insulin resistance, diabetes mellitus and hypertension. Nature 402(6764):880-883. doi:10.1038/47254

91. Pelham CJ, Ketsawatsomkron P, Groh S, Grobe JL, de Lange WJ, Ibeawuchi SR, Keen HL, Weatherford ET, Faraci FM, Sigmund CD (2012) Cullin-3 regulates vascular smooth muscle function and arterial blood pressure via PPARgamma and RhoA/ Rho-kinase. Cell Metab 16(4):462-472. doi:10.1016/j.cmet. 2012.08.011

92. Araki Y, Rai T, Sohara E, Mori T, Inoue Y, Isobe K, Kikuchi E, Ohta A, Sasaki S, Uchida S (2015) Generation and analysis of knock-in mice carrying pseudohypoaldosteronism type II-causing mutations in the cullin 3 gene. Biol Open 4(11):1509-1517. doi:10.1242/bio.013276

93. Ibeawuchi SR, Agbor LN, Quelle FW, Sigmund CD (2015) Hypertension-causing mutations in cullin3 protein impair RhoA protein ubiquitination and augment the association with substrate adaptors. J Biol Chem 290(31):19208-19217. doi:10. 1074/jbc.M115.645358

94. Bergaya S, Faure S, Baudrie V, Rio M, Escoubet B, Bonnin P, Henrion D, Loirand G, Achard J-M, Jeunemaitre X, Hadchouel J (2011) WNK1 regulates vasoconstriction and blood pressure response to $\alpha 1$-adrenergic stimulation in mice. Hypertension 58(3):439-445. doi:10.1161/hypertensionaha.111.172429

95. Zeniya M, Sohara E, Kita S, Iwamoto T, Susa K, Mori T, Oi K, Chiga M, Takahashi D, Yang SS, Lin SH, Rai T, Sasaki S, Uchida S (2013) Dietary salt intake regulates WNK3-SPAKNKCC1 phosphorylation cascade in mouse aorta through angiotensin II. Hypertension 62(5):872-878. doi:10.1161/ hypertensionaha.113.01543

96. Ko B, Mistry A, Hanson L, Mallick R, Hoover RS (2015) Mechanisms of angiotensin II stimulation of NCC are timedependent in MDCT15 cells. Am J Physiol Renal Physiol 308(7):F720-F727. doi:10.1152/ajprenal.00465.2014

97. Subramanya AR, Liu J, Ellison DH, Wade JB, Welling PA (2009) WNK4 diverts the thiazide-sensitive nacl cotransporter to the lysosome and stimulates AP-3 interaction. J Biol Chem 284(27):18471-18480. doi:10.1074/jbc.M109.008185

98. Yang CL, Liu X, Paliege A, Zhu X, Bachmann S, Dawson DC, Ellison DH (2007) WNK1 and WNK4 modulate CFTR activity. Biochem Biophys Res Commun 353(3):535-540. doi:10.1016/j. bbrc.2006.11.151

99. Mendes AI, Matos P, Moniz S, Luz S, Amaral MD, Farinha CM, Jordan P (2011) Antagonistic regulation of cystic fibrosis transmembrane conductance regulator cell surface expression by protein kinases WNK4 and spleen tyrosine kinase. Mol Cell Biol 31(19):4076-4086. doi:10.1128/mcb.05152-11

100. Luz S, Kongsuphol P, Mendes AI, Romeiras F, Sousa M, Schreiber R, Matos P, Jordan P, Mehta A, Amaral MD, Kunzelmann K, Farinha CM (2011) Contribution of casein kinase 2 and spleen tyrosine kinase to CFTR trafficking and protein kinase A-induced activity. Mol Cell Biol 31(22):4392-4404. doi:10.1128/mcb.05517-11

101. Lieberman J, Rodbard S (1975) Low blood pressure in young adults with cystic fibrosis: an effect of chronic salt loss in sweat? Ann Intern Med 82(6):806-808

102. Peotta VA, Bhandary P, Ogu U, Volk KA, Roghair RD (2014) Reduced blood pressure of CFTR-F508del carriers correlates with diminished arterial reactivity rather than circulating blood volume in mice. PLoS One 9(5):e96756. doi:10.1371/journal. pone. 0096756

103. Lu C, Pribanic S, Debonneville A, Jiang C, Rotin D (2007) The $\mathrm{PY}$ motif of $\mathrm{ENaC}$, mutated in Liddle syndrome, regulates channel internalization, sorting and mobilization from subapical pool. Traffic 8(9):1246-1264. doi:10.1111/j.1600-0854.2007. 00602.x

104. Náray-Fejes-Tóth A, Canessa C, Cleaveland ES, Aldrich G, Fejes-Tóth G (1999) SGK is an aldosterone-induced kinase in the renal collecting duct: effects on epithelial $\mathrm{Na}+$ channels. J Biol Chem 274(24):16973-16978. doi:10.1074/jbc.274.24. 16973

105. Debonneville C, Flores SY, Kamynina E, Plant PJ, Tauxe C, Thomas MA, Münster C, Chraïbi A, Pratt JH, Horisberger JD, Pearce D, Loffing J, Staub O (2001) Phosphorylation of NEDD4-2 by SGK1 regulates epithelial $\mathrm{Na}+$ channel cell surface expression. EMBO J 20(24):7052-7059. doi:10.1093/ emboj/20.24.7052

106. Chen SY, Bhargava A, Mastroberardino L, Meijer OC, Wang J, Buse P, Firestone GL, Verrey F, Pearce D (1999) Epithelial sodium channel regulated by aldosterone-induced protein SGK. Proc Natl Acad Sci USA 96(5):2514-2519

107. B-e Xu, Stippec S, Chu P-Y, Lazrak A, Li X-J, Lee B-H, English JM, Ortega B, Huang C-L, Cobb MH (2005) WNK1 activates SGK1 to regulate the epithelial sodium channel. Proc Natl Acad Sci USA 102(29):10315-10320. doi:10.1073/pnas.0504422102

108. Heise CJ, B-e Xu, Deaton SL, Cha S-K, Cheng C-J, Earnest S, Sengupta S, Juang Y-C, Stippec S, Xu Y, Zhao Y, Huang C-L, Cobb MH (2010) Serum and glucocorticoid-induced kinase (SGK) 1 and the epithelial sodium channel are regulated by multiple with no lysine (WNK) family members. J Biol Chem 285(33):25161-25167. doi:10.1074/jbc.M110.103432

109. Yu L, Cai H, Yue Q, Alli AA, Wang D, Al-Khalili O, Bao H-F, Eaton DC (2013) WNK4 inhibition of ENaC is independent of NEDD4-2-mediated ENaC ubiquitination. Am J Physiol Renal Physiol 305(1):F31-F41. doi:10.1152/ajprenal.00652.2012

110. Ring AM, Leng Q, Rinehart J, Wilson FH, Kahle KT, Hebert SC, Lifton RP (2007) An SGK1 site in WNK4 regulates Na+ channel and $\mathrm{K}+$ channel activity and has implications for aldosterone signaling and $\mathrm{K}+$ homeostasis. Proc Natl Acad Sci 104(10):4025-4029. doi:10.1073/pnas.0611728104

111. He G, Wang HR, Huang SK, Huang CL (2007) Intersectin links WNK kinases to endocytosis of ROMK1. J Clin Invest 117(4):1078-1087. doi:10.1172/jci30087

112. Cope G, Murthy M, Golbang AP, Hamad A, Liu CH, Cuthbert AW, O'Shaughnessy KM (2006) WNK1 affects surface expression of the ROMK potassium channel independent of WNK4. J Am Soc Nephrol 17(7):1867-1874. doi:10.1681/asn.2005111224

113. O'Donnell ME (1993) Role of $\mathrm{Na}-\mathrm{K}-\mathrm{Cl}$ cotransport in vascular endothelial cell volume regulation. Am J Physiol 264(5 Pt 1):C1316-C1326

114. Chipperfield AR, Harper AA (2000) Chloride in smooth muscle. Prog Biophys Mol Biol 74(3-5):175-221. doi:10.1016/S00796107(00)00024-9

115. Meyer JW, Flagella M, Sutliff RL, Lorenz JN, Nieman ML, Weber CS, Paul RJ, Shull GE (2002) Decreased blood pressure and vascular smooth muscle tone in mice lacking basolateral $\mathrm{Na}+-\mathrm{K}+-2 \mathrm{Cl}-$ cotransporter. Am J Physiol Heart Circ Physiol 283(5):H1846-H1855. doi:10.1152/ajpheart.00083.2002

116. Garg P, Martin CF, Elms SC, Gordon FJ, Wall SM, Garland CJ, Sutliff RL, O'Neill WC (2007) Effect of the $\mathrm{Na}-\mathrm{K}-2 \mathrm{Cl}$ cotransporter NKCC1 on systemic blood pressure and smooth muscle tone. Am J Physiol Heart Circ Physiol 292(5):H2100 H2105. doi:10.1152/ajpheart.01402.2006

117. Lai J-G, Tsai S-M, Tu H-C, Chen W-C, Kou F-J, Lu J-W, Wang $\mathrm{H}-\mathrm{D}$, Huang C-L, Yuh C-H (2014) Zebrafish wnk lysine deficient 
protein kinase 1 (wnkl) affects angiogenesis associated with VEGF signaling. PLoS One 9(8):e106129. doi:10.1371/journal. pone. 0106129

118. Vitari AC, Deak M, Collins BJ, Morrice N, Prescott AR, Phelan A, Humphreys S, Alessi DR (2004) WNK1, the kinase mutated in an inherited high-blood-pressure syndrome, is a novel PKB (protein kinase B)/AKT substrate. Biochem J 378(1):257-268. doi:10.1042/bj20031692

119. Jiang ZY, Zhou QL, Holik J, Patel S, Leszyk J, Coleman K, Chouinard M, Czech MP (2005) Identification of WNK1 as a substrate of AKT/protein kinase B and A negative regulator of insulin-stimulated mitogenesis in 3T3-L1 cells. J Biol Chem 280(22):21622-21628. doi:10.1074/jbc.M414464200

120. Nishida H, Sohara E, Nomura N, Chiga M, Alessi DR, Rai T, Sasaki S, Uchida S (2012) Phosphatidylinositol 3-kinase/AKT signaling pathway activates the WNK-OSR1/SPAK-NCC phosphorylation cascade in hyperinsulinemic $\mathrm{db} / \mathrm{db}$ mice. Hypertension 60(4):981-990. doi:10.1161/hypertensionaha.112. 201509

121. Small HY, Montezano AC, Rios FJ, Savoia C, Touyz RM (2014) Hypertension due to antiangiogenic cancer therapy with vascular endothelial growth factor inhibitors: understanding and managing a new syndrome. Can J Cardiol 30(5):534-543. doi:10.1016/j.cjca.2014.02.011

122. Qi W-X, He A-N, Shen Z, Yao Y (2013) Incidence and risk of hypertension with a novel multi-targeted kinase inhibitor axitinib in cancer patients: a systematic review and meta-analysis. Br J Clin Pharmacol 76(3):348-357. doi:10.1111/bcp.12149

123. Kikuchi E, Mori T, Zeniya M, Isobe K, Ishigami-Yuasa M, Fujii S, Kagechika H, Ishihara T, Mizushima T, Sasaki S, Sohara E, Rai T, Uchida S (2015) Discovery of novel SPAK inhibitors that block WNK kinase signaling to cation chloride transporters. J Am Soc Nephrol 26(7):1525-1536. doi:10.1681/asn.2014060560
124. Yamada K, Park H-M, Rigel DF, DiPetrillo K, Whalen EJ, Anisowicz A, Beil M, Berstler J, Brocklehurst CE, Burdick DA, Caplan SL, Capparelli MP, Chen G, Chen W, Dale B, Deng L, Fu F, Hamamatsu N, Harasaki K, Herr T, Hoffmann P, Hu Q-Y, Huang W-J, Idamakanti N, Imase $\mathrm{H}$, Iwaki $\mathrm{Y}$, Jain $\mathrm{M}$, Jeyaseelan J, Kato M, Kaushik VK, Kohls D, Kunjathoor V, LaSala D, Lee J, Liu J, Luo Y, Ma F, Mo R, Mowbray S, Mogi M, Ossola F, Pandey P, Patel SJ, Raghavan S, Salem B, Shanado YH, Trakshel GM, Turner G, Wakai H, Wang C, Weldon S, Wielicki JB, Xie X, Xu L, Yagi YI, Yasoshima K, Yin J, Yowe D, Zhang J-H, Zheng G, Monovich L (2016) Small-molecule WNK inhibition regulates cardiovascular and renal function. Nat Chem Biol Adv Online Publ. doi:10.1038/nchembio.2168. http://www.nature.com/nchembio/journal/vaop/ncurrent/abs/ nchembio.2168.html\#supplementary-information

125. Saritas T, Borschewski A, McCormick JA, Paliege A, Dathe C, Uchida S, Terker A, Himmerkus N, Bleich M, Demaretz S, Laghmani K, Delpire E, Ellison DH, Bachmann S, Mutig K (2013) Spak differentially mediates vasopressin effects on sodium cotransporters. J Am Soc Nephrol 24(3):407-418. doi:10.1681/asn.2012040404

126. Cheng CJ, Yoon J, Baum M, Huang CL (2015) Ste20/sps1related proline/alanine-rich kinase (SPAK) is critical for sodium reabsorption in isolated, perfused thick ascending limb. Am J Physiol Renal Physiol 308(5):F437-F443. doi:10.1152/ajprenal. 00493.2013

127. Grimm PR, Lazo-Fernandez Y, Delpire E, Wall SM, Dorsey SG, Weinman EJ, Coleman R, Wade JB, Welling PA (2015) Integrated compensatory network is activated in the absence of NCC phosphorylation. J Clin Invest 125(5):2136-2150. doi:10.1172/ jci78558 